Zoltan Timar-Geng • Bernhard Fügenschuh Andreas Wetzel · Horst Dresmann

\title{
Low-temperature thermochronology of the flanks of the southern Upper Rhine Graben
}

Received: 6 June 2005/ Accepted: 22 October 2005/Published online: 14 December 2005

(C) Springer-Verlag 2005

\begin{abstract}
The Upper Rhine Graben (URG) is the most perceptible part of the European Cenozoic Rift System. Uplifted Variscan basement of the Black Forest and the Vosges forms the flanks of the southern part of the graben. Apatite and zircon fission-track (FT) analyses indicate a complex low-temperature thermal history of the basement that was deciphered by inverse modelling of FT parameters. The models were tested against the observed data and independent geological constraints. The zircon FT ages of 28 outcrop samples taken along an $\mathrm{E}-\mathrm{W}$ trending transect across the Black Forest and the Vosges range from 136 to $312 \mathrm{Ma}$, the apatite FT ages from 20 to $83 \mathrm{Ma}$. The frequency distributions of confined track lengths are broad and often bimodal in shape indicating a complex thermal history. Cooling below $120^{\circ} \mathrm{C}$ in the Early Cretaceous to Palaeogene was followed by a discrete heating episode during the late Eocene and subsequent cooling to surface temperature. The modelled time-temperature $(t-T)$ paths point to a total denudation of the flanks of URG in the range of $1.0-1.7 \mathrm{~km}$ for a paleogeothermal gradient of $60^{\circ} \mathrm{C} / \mathrm{km}$, and $1.3-2.2 \mathrm{~km}$ for a paleogeothermal gradient of $45^{\circ} \mathrm{C} /$ $\mathrm{km}$ since the late Eocene.
\end{abstract}

Keywords Upper Rhine Graben · Black Forest · Vosges $\cdot$ Fission-track $\cdot$ Low-temperature thermal history

Z. Timar-Geng $(\bowtie) \cdot$ B. Fügenschuh $\cdot$ A. Wetzel $\cdot$ H. Dresmann Geologisch-Paläontologisches Institut, Universität Basel, Bernoullistrasse 32, 4056 Basel, Switzerland

E-mail: zoltan.timar-geng@geologie.uni-freiburg.de

Tel.: + 49-761-2036477

Fax: + 49-761-2036496

Present address: Z. Timar-Geng

Geologisches Institut, Albert-Ludwigs-Universität Freiburg,

Albertstr. 23b, 79104 Freiburg, Germany

\section{Introduction}

The Upper Rhine Graben (URG) forms part of a complex Cenozoic rift system that extends over a distance of more than $1,000 \mathrm{~km}$ from the North Sea to the western Mediterranean (Fig. 1). The N-NE trending southern branch of the URG is flanked by uplifted Variscan basement, exposed in the Black Forest and Vosges, and limited to the south by the Swiss Jura Mountains.

In the last decades, a large amount of geological and geophysical data has been collected by evaluating the structure of the URG (e.g. Rothé and Sauer 1967; Illies and Müller 1970; Illies and Fuchs 1974; Fuchs et al. 1987; Prodehl et al. 1995) and its Cenozoic evolution (e.g. Schumacher 2002; Dèzes et al. 2004). The URG developed in the foreland of the Alps by passive rifting in response to the elevated collision-related compressional intraplate stresses (Dèzes et al. 2004). Thus, the Cenozoic uplift and exhumation history of the Black Forest and Vosges may reflect changes in the interplay between the Alpine orogenic wedge and its foreland (Schumacher 2002) as well as onset of plume-type upwelling of the sub-lithospheric mantle and thermal weakening of the foreland lithosphere (Dèzes et al. 2004). In this context, it is of particular interest to closely constrain the low-temperature thermochronology of the strongly uplifted flanks of the southern URG as this especially may reveal the timing and magnitude of distinct heating and cooling events. Furthermore, there are still some ambiguities concerning the overall picture. For example, the time lag between Late Eocene initial graben formation and Middle to Late Miocene flank uplift suggests that these two phases are not closely related. In addition, the amount of rift flank exhumation in the southern part significantly exceeds that in the north.

Fission-track (FT) analysis is a suitable method, particularly to reconstruct the low-temperature thermal history of the uppermost parts of the crust. It has 
Fig. 1 The European Cenozoic Rift System in the foreland of the Alps (after Dèzes et al. 2004). BF Black Forest, $B G$ Bresse Graben, EG Eger Graben, FP Franconian Platform, $H G$ Hessian grabens, $L G$ Limagne Graben, $L R G$ Lower Rhine Graben, $O W$ Odenwald, $U R G$ Upper Rhine Graben, $V G$ Vosges

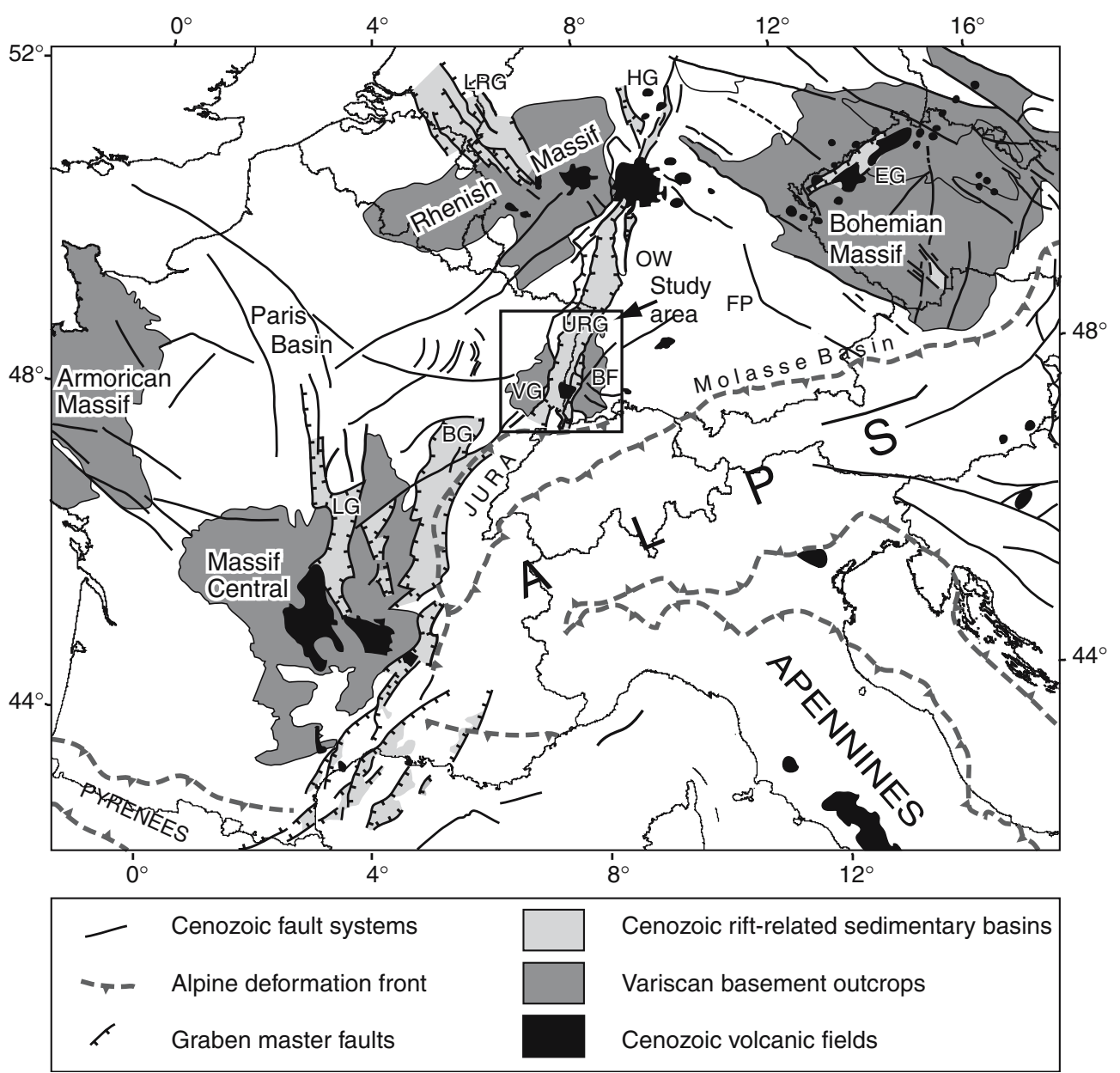

already been successfully applied to continental extension zones (e.g. Foster et al. 1993; Foster and Gleadow 1996; Foster and Raza 2002). Existing apatite FT data (Michalski 1987; Wagner 1990; Hurford and Carter 1994; Wyss 2001) from the southern URG area roughly document the Late Cretaceous to Tertiary cooling history of the Black Forest and Vosges. These apatite FT ages cluster around 80-100, 55-70 and 30-40 Ma and indicate slow overall cooling since the Middle Cretaceous. These early studies revealed pronounced block faulting and an increased paleogeothermal gradient, which have been related to the formation of the URG (Michalski 1987; Wagner et al. 1989; Wagner 1990). However, to provide a more comprehensive analysis, it is desirable to include the track length distributions, which have a direct record of the temperatures experienced since accumulation of the tracks. Together with the FT age, they can be used to reconstruct quantitatively the thermal history.

It is the purpose of the present investigation to elucidate the low-temperature thermal history of the flanks of the southern URG. Based on new zircon and apatite FT data from basement rocks sampled along two E-W trending transects in the Black Forest and the Vosges (Fig. 2), the thermal history was evaluated by an inverse modelling procedure.

\section{Post-Variscan evolution}

After the late Variscan consolidation of the crust, the mountain range in the today's area of the southern URG was eroded forming a peneplain at the Permian/Triassic transition (Geyer and Gwinner 1991). Compared to the late Paleozoic, the Mesozoic was a period of relative tectonic inactivity characterised by subsidence and marine transgression. A series of up to $1,500 \mathrm{~m}$ well-stratified Triassic to Jurassic sediments accumulated on PermoCarboniferous sedimentary rocks or on the crystalline basement (Geyer and Gwinner 1991). Only minor Jurassic reactivation of pre-existing basement structures led to synsedimentary deformation and some variations in thickness and facies (Wetzel et al. 2003). Contemporaneous substantial hydrothermal activity is evidenced by many vein-type mineralizations of Mesozoic age (e.g. von Gehlen 1987; Wernicke and Lippolt 1997; see compilation by Wetzel et al. 2003). Zircon FT data indicate that circulating hydrothermal fluids with temperatures in the order of $200-250^{\circ} \mathrm{C}$ significantly altered the paleotemperature field in the upper crust during Mesozoic times (Timar-Geng et al. 2004). In the southern URG area large-scale domal uplift commenced towards the end of the Jurassic (Illies 1977; Geyer and Gwinner 1991). Cre- 


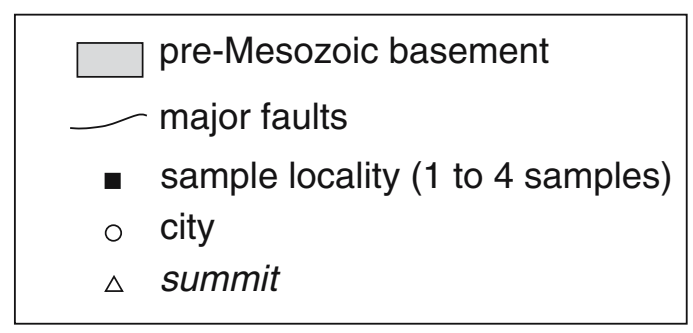

a
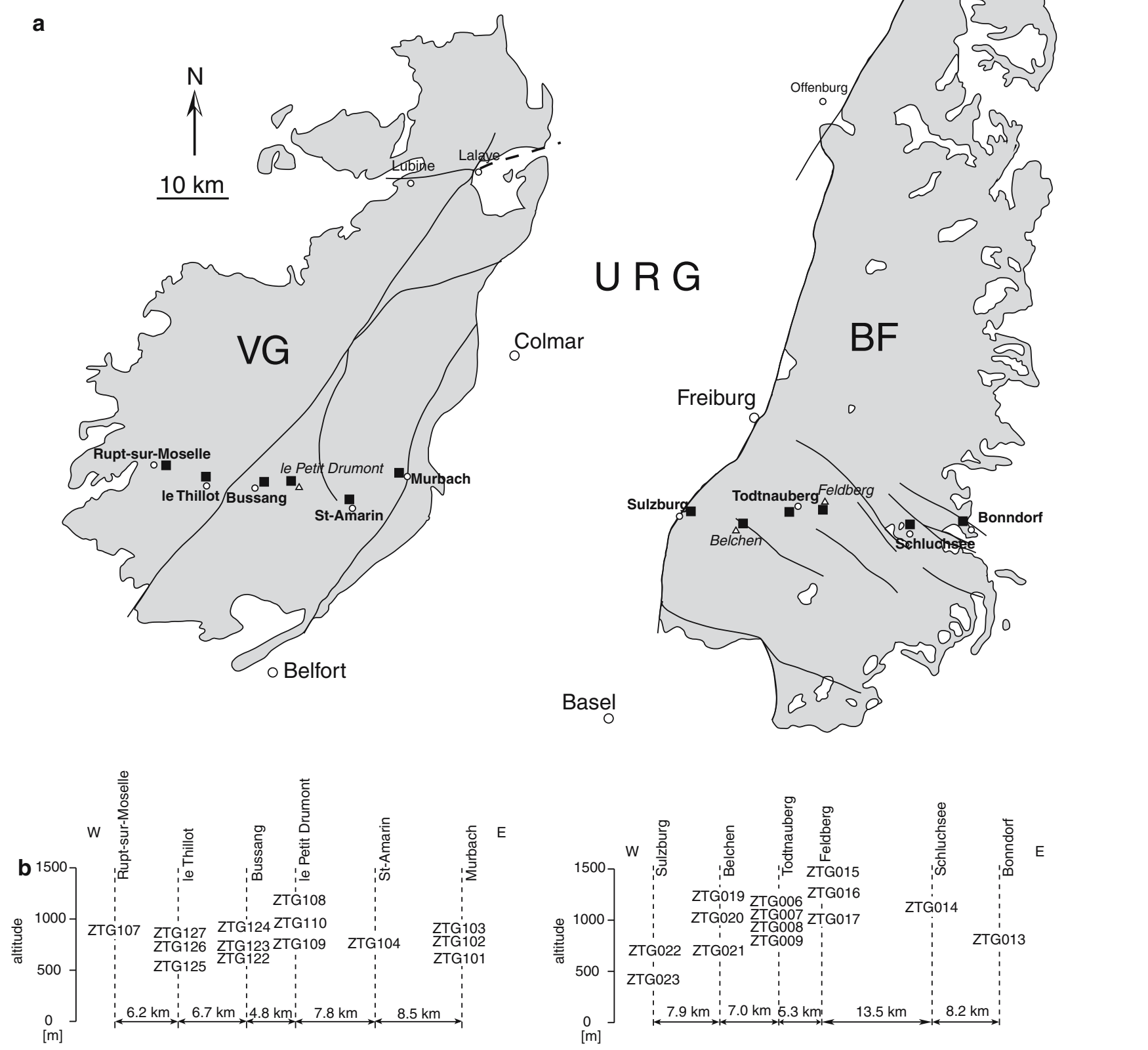

Fig. 2 a Outline of the outcropping Variscan basement forming the flanks of the southern Upper Rhine Graben with sample localities for fission-track analysis. BF Black Forest, $U R G$ Upper Rhine Graben, $V G$ Vosges. b Schematic E-W profile showing the elevation of samples

taceous to Palaeogene deposits are absent in this area. However, it is still a matter of debate, if Cretaceous sediments were completely eroded during latest Cretaceous and Paleocene times (Ziegler 1990) or if they were never deposited (e.g. Geyer and Gwinner 1991).
The Cenozoic evolution of the southern URG area is characterised by renewed tectonic activity reflecting the interaction of the Alpine orogen with its foreland (Dèzes et al. 2004). Rifting and subsidence of the URG started with the nucleation of Middle to Late Eocene local basins, 
which further evolved and became connected under repeatedly changing stress fields, and remained active until the present (Schumacher 2002). Middle Miocene large-scale uplift of the Black Forest and the Vosges due to lithospheric folding was controlled by NW-directed compressional stresses built up in the Alpine foreland (Dèzes et al. 2004). The volcanic activity started slightly before the initial graben formation, but remained active until Miocene times (Keller et al. 2002). The associated mantle upwelling system beneath the Alpine foreland caused thermal weakening of the lithosphere (Ziegler et al. 1995).

Neotectonic activity is clearly shown by deformed Pliocene fluvial gravels (Giamboni et al. 2004), and the elevated seismic activity as evident by strong historical earthquakes in the URG area. Fault-plane solutions of recent earthquakes document ongoing sinistral strikeand oblique-slip movements in the URG as a result of NNW-SSE oriented compression (Werner and Franzke 2001).

\section{Fission-track thermochronology}

The FT dating is a radiometric dating method to determine a FT age of uranium bearing minerals like zircon and apatite (for a detailed overview see, e.g.
Gallagher et al. 1998; Gleadow and Brown 2000). The spontaneous fission of ${ }^{238} \mathrm{U}$ leaves a trail of damage in the crystal lattice (Price and Walker 1962a, b). From the number of tracks formed since the crystal for the last time cooled below the track retention temperature, a FT age can be calculated. Because of a process called annealing (e.g. Naeser 1979), a geologic meaning can rarely be ascribed to such an age. In a wide temperature range, referred to as partial annealing zone (PAZ, e.g. Wagner 1979), fission tracks gradually shorten and at even higher temperatures disappear completely over geological time. As a result, FT ages are often younger than the conventional ( $\mathrm{U}-\mathrm{Pb}$ and $\mathrm{K}$ Ar) radiometric ages of the same samples. This, at first sight, disturbing characteristic of the annealing process turned out to be a key feature that enables the FT method to become a unique tool for deciphering the thermochronology of rocks. Temperature is the most important factor that causes annealing and, consequently, controls the degree of track shortening. Therefore, the track length distribution of a sample yields significant thermal history information over a protracted temperature range. In practice, from the single grain age and track length data a detailed thermal history can be constructed, rather than just an estimate of the timing when the sample cooled through the closure temperature.

Table 1 Zircon FT data of the Black Forest and Vosges

\begin{tabular}{|c|c|c|c|c|c|c|c|c|c|c|}
\hline $\begin{array}{l}\text { Sample } \\
\text { number }\end{array}$ & $\begin{array}{l}\text { Coordinates } \\
\text { (GK3) }\end{array}$ & $\begin{array}{l}\text { Elevation } \\
(\mathrm{m})\end{array}$ & Rock type & $\begin{array}{l}\text { Number of } \\
\text { crystals } \\
\text { counted }\end{array}$ & $\begin{array}{l}\text { Spontaneous } \\
\text { tracks } \rho_{\mathrm{s}}\left(N_{\mathrm{s}}\right)\end{array}$ & $\begin{array}{l}\text { Induced } \\
\text { tracks } \\
\rho_{\mathrm{i}}\left(N_{\mathrm{i}}\right)\end{array}$ & $\begin{array}{l}P\left(\chi^{2}\right) \\
(\%)\end{array}$ & $\begin{array}{l}\text { Dosimeter } \\
\rho_{\mathrm{d}}\left(N_{\mathrm{d}}\right)\end{array}$ & Disp. & $\begin{array}{l}\text { Central age } \\
(\mathrm{Ma}) \pm 1 \sigma\end{array}$ \\
\hline \multicolumn{11}{|c|}{ Black Forest } \\
\hline ZTG006 & 3420040,5301820 & 1,085 & Anatectic gneiss & 20 & $183(1737)$ & 15 (139) & 56 & $4.51(1732)$ & 0.05 & $312 \pm 29$ \\
\hline ZTG007 & 3420005,5301405 & 1,010 & Anatectic gneiss & 20 & $200(1485)$ & $17(123)$ & 89 & $4.18(1605)$ & 0.00 & $280 \pm 28$ \\
\hline ZTG008 & 3419990,5301285 & 960 & Anatectic gneiss & 20 & $133(1196)$ & $13(113)$ & 96 & $4.44(1705)$ & 0.00 & $262 \pm 27$ \\
\hline ZTG009 & 3419815,5301280 & 860 & Anatectic gneiss & 20 & $243(1675)$ & $26(179)$ & 67 & $4.90(1882)$ & 0.02 & $255 \pm 22$ \\
\hline ZTG013 & 3448455,5299915 & 770 & Granite & 20 & $305(2101)$ & $55(379)$ & $<0.001$ & $4.84(1859)$ & 0.50 & $146 \pm 19$ \\
\hline ZTG014 & 3438620,5299295 & 1,100 & Granite & 9 & $274(514)$ & $52(97)$ & 63 & $4.57(1755)$ & 0.49 & $136 \pm 16$ \\
\hline ZTG015 & 3425620,5304330 & 1,480 & Anatectic gneiss & 20 & $250(1515)$ & $23(141)$ & 91 & $4.77(1832)$ & 0.01 & $285 \pm 26$ \\
\hline ZTG016 & 3426215,5303360 & 1,250 & Orthogneiss & 14 & $257(834)$ & $22(72)$ & 96 & $4.31(1655)$ & 0.00 & $277 \pm 35$ \\
\hline ZTG017 & 3425355,5302705 & 980 & Paragneiss & 20 & $319(2214)$ & $27(185)$ & 85 & $3.66(1405)$ & 0.00 & $244 \pm 20$ \\
\hline ZTG019 & 3412965,5299095 & 1,210 & Anatectic gneiss & 17 & $118(1285)$ & $11(124)$ & 46 & $4.70(1805)$ & 0.13 & $269 \pm 28$ \\
\hline ZTG020 & 3412925,5299685 & 1,000 & Anatectic gneiss & 17 & $292(1431)$ & $27(130)$ & 22 & $4.64(1782)$ & 0.19 & $282 \pm 31$ \\
\hline ZTG021 & 3412150,5300195 & 690 & Anatectic gneiss & 20 & $203(1090)$ & $23(125)$ & 22 & $4.05(1555)$ & 0.22 & $195 \pm 22$ \\
\hline ZTG022 & 3404790,5301740 & 690 & Paragneiss & 20 & $267(1269)$ & $30(143)$ & 55 & $3.92(1505)$ & 0.07 & $194 \pm 18$ \\
\hline ZTG023 & 3403780,5301265 & 400 & Paragneiss & 20 & $231(1671)$ & $25(182)$ & 39 & $3.99(1532)$ & 0.08 & $204 \pm 18$ \\
\hline \multicolumn{11}{|l|}{ Vosges } \\
\hline ZTG101 & 3360955,5310900 & 605 & Granite & 4 & $352(318)$ & $42(38)$ & 32 & $4.01(1540)$ & 0.10 & $184 \pm 34$ \\
\hline ZTG102 & 3360440,5310740 & 760 & Granite & 17 & $341(1015)$ & $38(113)$ & 3.5 & $4.12(1582)$ & 0.32 & $202 \pm 26$ \\
\hline ZTG103 & 3360155,5310970 & 850 & Granite & 15 & $313(1000)$ & $44(141)$ & 45 & $4.10(1574)$ & 0.06 & $163 \pm 16$ \\
\hline ZTG107 & 3327230,5312175 & 840 & Granite & 6 & $454(410)$ & $55(50)$ & 95 & $3.98(1528)$ & 0.00 & $182 \pm 28$ \\
\hline ZTG108 & 3344305,5309310 & 1,200 & Granite & 20 & $450(1000)$ & $45(101)$ & 66 & $4.07(1563)$ & 0.00 & $225 \pm 24$ \\
\hline ZTG109 & 3342910,5310030 & 740 & Granite & 20 & 371 (969) & $46(120)$ & 99 & $3.99(1532)$ & 0.00 & $180 \pm 18$ \\
\hline ZTG110 & 3343230,5309100 & 960 & Granite & 7 & $460(359)$ & $46(36)$ & 89 & $4.15(1594)$ & 0.00 & $231 \pm 41$ \\
\hline ZTG123 & 3340290,5308750 & 750 & Granite & 11 & $432(727)$ & $52(88)$ & 6 & $4.38(1682)$ & 0.28 & $200 \pm 29$ \\
\hline ZTG124 & 3340440,5309340 & 880 & Granite & 4 & $612(209)$ & $59(20)$ & 44 & $4.36(1674)$ & 0.00 & $254 \pm 60$ \\
\hline ZTG125 & 3332465,5308815 & 560 & Granite & 11 & $458(637)$ & $58(81)$ & 99 & $4.08(1567)$ & 0.00 & $180 \pm 22$ \\
\hline ZTG127 & 3333085,5310170 & 825 & Granite & 20 & 408 (836) & $43(88)$ & 96 & $4.13(1586)$ & 0.00 & $219 \pm 25$ \\
\hline
\end{tabular}

Track densities $(\rho)$ are in $10^{5}$ tracks $/ \mathrm{cm}^{2}$, number of tracks counted $(N)$ shown in brackets. Analyses by external detector method using 0.5 for the $4 \pi / 2 \pi$ geometry correction factor. Disp. $=$ Dispersion, according to Galbraith and Laslett (1993). Ages calculated as central ages according to Galbraith and Laslett (1993) using dosimeter glass CN1 with $\zeta_{\mathrm{CN} 1}=113.49 \pm 1.80$ (Z. Timar-Geng). $P\left(\chi^{2}\right)$ is the probability of obtaining $\chi^{2}$ value for $v$ degrees of freedom where $v=$ number of crystals -1 
Table 2 Apatite FT data of the Black Forest and Vosges

\begin{tabular}{|c|c|c|c|c|c|c|c|c|c|c|}
\hline $\begin{array}{l}\text { Sample } \\
\text { number }\end{array}$ & $\begin{array}{l}\text { Coordinates } \\
\text { (GK3) }\end{array}$ & $\begin{array}{l}\text { Elevation } \\
(\mathrm{m})\end{array}$ & Rock type & $\begin{array}{l}\text { Number } \\
\text { of crystals } \\
\text { counted }\end{array}$ & $\begin{array}{l}\text { Spontaneous } \\
\text { tracks } \rho_{\mathrm{s}}\left(N_{\mathrm{s}}\right)\end{array}$ & $\begin{array}{l}\text { Induced } \\
\text { tracks } \\
\rho_{\mathrm{i}}\left(N_{\mathrm{i}}\right)\end{array}$ & $\begin{array}{l}P\left(\chi^{2}\right) \\
(\%)\end{array}$ & $\begin{array}{l}\text { Dosimeter } \\
\rho_{\mathrm{d}}\left(N_{\mathrm{d}}\right)\end{array}$ & Disp. & $\begin{array}{l}\text { Central } \\
\text { age } \\
(\mathrm{Ma}) \pm 1 \sigma\end{array}$ \\
\hline \multicolumn{11}{|c|}{ Black Forest } \\
\hline ZTG006 & 3420040,5301820 & 1,085 & Anatectic gneiss & 20 & $18(787)$ & $48(2084)$ & $<0.001$ & $8.19(3143)$ & 0.30 & $54 \pm 5$ \\
\hline ZTG007 & 3420005,5301405 & 1,010 & Anatectic gneiss & 20 & 7 (309) & $19(886)$ & 0.6 & $8.84(3393)$ & 0.29 & $53 \pm 5$ \\
\hline ZTG008 & 3419990,5301285 & 960 & Anatectic gneiss & 20 & $13(827)$ & $21(1329)$ & 26 & $7.55(2898)$ & 0.04 & $81 \pm 4$ \\
\hline ZTG009 & 3419815,5301280 & 860 & Anatectic gneiss & 20 & $6(345)$ & $14(831)$ & $<0.001$ & $9.16(3516)$ & 0.52 & $83 \pm 12$ \\
\hline ZTG013 & 3448455,5299915 & 770 & Granite & 20 & $9(704)$ & $17(1408)$ & 65 & $7.01(2689)$ & 0.02 & $60 \pm 3$ \\
\hline ZTG014 & 3438620,5299295 & 1,100 & Granite & 20 & $8(463)$ & $32(1794)$ & 0.1 & $9.06(3475)$ & 0.25 & $42 \pm 4$ \\
\hline ZTG015 & 3425620,5304330 & 1,480 & Anatectic gneiss & 20 & $13(720)$ & $43(2479)$ & 1.7 & $10.09(3871)$ & 0.16 & $51 \pm 3$ \\
\hline ZTG016 & 3426215,5303360 & 1,250 & Orthogneiss & 20 & 20( & $50(3151)$ & $<0.001$ & $6.67(2559)$ & 0.16 & $46 \pm 3$ \\
\hline ZTG017 & 3425355,5302705 & 980 & Paragneiss & 20 & $22(936)$ & 69 (2919) & 1.4 & $10.43(4001)$ & 0.16 & $56 \pm 4$ \\
\hline ZTG019 & 3412965,5299095 & 1,210 & Anatectic gneiss & 20 & $14(639)$ & $41(1870)$ & $<0.001$ & $8.72(3345)$ & 0.24 & $51 \pm 4$ \\
\hline ZTG020 & 3412925,5299685 & 1,000 & Anatectic gneiss & 20 & $6(254)$ & $36(1572)$ & 40 & $7.36(2823)$ & 0.13 & $20 \pm 2$ \\
\hline ZTG021 & 3412150,5300195 & 690 & Anatectic gneiss & 20 & 4 (199) & 35 (1649) & $<0.001$ & $10.45(4011)$ & 0.56 & $27 \pm 4$ \\
\hline ZTG022 & 3404790,5301740 & 690 & Paragneiss & 20 & $9(320)$ & $66(2371)$ & $<0.001$ & $9.81(3765)$ & 0.51 & $20 \pm 3$ \\
\hline ZTG023 & 3403780,5301265 & 400 & Paragneiss & 20 & $14(826)$ & $76(4540)$ & $<0.001$ & $10.13(3888)$ & 0.26 & $33 \pm 3$ \\
\hline \multicolumn{11}{|c|}{ Vosges } \\
\hline ZTG101 & 3360955,5310900 & 605 & ( & 20 & 5) & 760) & $=0.001$ & 10.94 & 0.26 & $40 \pm 3$ \\
\hline ZTG102 & 3360440,5310740 & 760 & $\mathrm{Gr}$ & 20 & 17( & $69(2733)$ & 0.9 & $9.00(3458)$ & 0.17 & $38 \pm 3$ \\
\hline ZTG103 & 3360155,5310970 & 850 & Grai & 20 & 21 & $896)$ & 8 & $11.64(4472)$ & 0.10 & $48 \pm 3$ \\
\hline ZTG104 & 3352140,5307635 & 750 & Granite & 20 & $7(329)$ & $28(1327)$ & 6 & $10.58(4065)$ & 0.19 & $45 \pm 4$ \\
\hline ZTG107 & 3327230,5312175 & 840 & Granite & 20 & $5(236)$ & $30(1292)$ & 27 & $11.29(4338)$ & 0.12 & $36 \pm 3$ \\
\hline ZTG108 & 3344305,5309310 & 1,200 & Granite & 20 & $14(673)$ & $38(1747)$ & 46 & $10.76(4134)$ & 0.02 & $71 \pm 4$ \\
\hline ZTG109 & 3342910,5310030 & 740 & Granite & 20 & $13(656)$ & $45(2227)$ & 3.4 & $10.23(3930)$ & 0.15 & $52 \pm 3$ \\
\hline ZTG110 & 3343230,5309100 & 960 & Granite & 20 & $7(311)$ & $21(955)$ & $<0.001$ & $10.05(3861)$ & 0.37 & $61 \pm 7$ \\
\hline ZTG122 & 3339230,5310445 & 640 & Granite & 20 & $4(289)$ & $27(1911)$ & $<0.001$ & $9.96(3827)$ & 0.36 & $26 \pm 3$ \\
\hline ZTG123 & 3340290,5308750 & 750 & Granite & 20 & $5(363)$ & $23(1514)$ & 1.9 & $9.70(3728)$ & 0.20 & $40 \pm 3$ \\
\hline ZTG124 & 3340440,5309340 & 880 & Granite & 20 & $10(544)$ & $29(1569)$ & 5 & 12.49 (4799) & 0.16 & $75 \pm 5$ \\
\hline ZTG125 & 3332465,5308815 & 560 & Granite & 20 & $10(416)$ & $41(1639)$ & $<0.001$ & $12.19(4683)$ & 0.25 & $61 \pm 5$ \\
\hline ZTG126 & 3333255,5309805 & 730 & Granite & 20 & $20(601)$ & 59 (1819) & $<0.001$ & $11.89(4568)$ & 0.33 & $71 \pm 7$ \\
\hline ZTG127 & 3333085,5310170 & 825 & Granite & 20 & $13(471)$ & 37 (1313) & 1.9 & $9.70(3727)$ & 0.20 & $61 \pm 5$ \\
\hline
\end{tabular}

Track densities $(\rho)$ are in $10^{5}$ tracks $/ \mathrm{cm}^{2}$, number of tracks counted $(N)$ shown in brackets. Analyses by external detector method using 0.5 for the $4 \pi / 2 \pi$ geometry correction factor. Disp., Dispersion, according to Galbraith and Laslett (1993). Ages calculated as central ages according to Galbraith and Laslett (1993) using dosimeter glass CN5 with $\zeta_{\mathrm{CN} 5}=345.69 \pm 8.75$ (Z. Timar-Geng). $P\left(\chi^{2}\right)$ is the probability of obtaining $\chi^{2}$ value for $v$ degrees of freedom where $v=$ number of crystals -1

In the last decades, several annealing models for apatite have been developed to characterise FT annealing as function of time and temperature (e.g. Laslett et al. 1987; Carlson 1990; Crowley et al. 1991; Laslett and Galbraith 1996; Ketcham et al. 1999). With an inverse modelling approach, including generation of candidate $t-T$ paths and statistical evaluation of the goodness-of-fit between model predictions and the observed data, it is possible to determine a range of thermal histories that are consistent with both the measured FT age and track length distribution (Ketcham et al. 2000). However, it has to be kept in mind that this approach does not provide an unequivocal answer in terms of a strict mathematical inversion, but offers a wide range of $t-T$ paths that could produce the measured data. It is the task of a geologist to find the "geologically reasonable" model by constraining the range of possible thermal histories based on independent geologic evidence.

\section{Methodological details}

Twenty-eight basement samples were collected for FT analysis along an $\mathrm{E}-\mathrm{W}$ oriented transect across the southern Vosges and the southern Black Forest (Fig. 2 and Table. 1,2). Apatite and zircon samples were separated by using conventional magnetic and heavy liquid techniques. After mounting in epoxy resin (apatite) and PFA $^{\circledR}$ Teflon (zircon), grinding, and polishing, apatites were etched for $40 \mathrm{~s}$ in $6.5 \% \mathrm{HNO}_{3}$ at room temperature and zircons for 6-13 h in a $\mathrm{KOH}-\mathrm{NaOH}$ eutectic melt at $220^{\circ} \mathrm{C}$. Thermal neutron irradiation was performed at the Australian Nuclear Science and Technology Organisation (ANSTO) facility, Lucas Heights, Australia. External mica detectors were etched for $40 \mathrm{~min}$ in $40 \%$ HF at room temperature. Track counting and track length measurements were carried out under an optical microscope ("Axioscope" by Zeiss) with the aid of a computer driven stage (Dumitru 1993). The magnification applied was $1,600 \times$ using a dry objective for apatite FT analysis (both for track counting and confined track length measurement) and 2,500 $\times$ using an oil immersion objective for zircon FT analysis. Samples were dated by the external detector method (Naeser 1976; Gleadow 1981) applying the zeta approach (Hurford and Green 1982,1983 ) with a zeta value of $345.69 \pm 8.75$ (Durango, CN5) for apatite and $113.49 \pm 1.80$ (Fish Canyon Tuff, $\mathrm{CN} 1)$ for zircon. FT ages and their graphical represen- 
tations were calculated and generated by using the computer program Trackkey (Dunkl 2002). All FT ages are displayed as central ages (Galbraith and Laslett 1993) and errors are quoted as $\pm 1 \sigma$.

\section{Fission-track results}

Twenty-five new zircon FT ages and twenty-eight new apatite FT ages are presented according to the I.U.G.S. recommendations (Hurford 1990) together with details of the measurement in Tables 1 and 2. Zircon and apatite FT ages, radial plots (Galbraith 1988, 1990) of single grain ages, and track length distributions are shown in Figs. 3, 4, 5, 6, 7, 8 and 9. Both zircon and apatite FT ages of the samples collected on the two flanks of the southern URG are very similar and cover the entire age range found by previous studies (Michalski 1987; Hurford and Carter 1994; Wyss 2001; Timar-Geng et al. 2004).

\section{Black Forest}

Fourteen basement samples were collected along an E$\mathrm{W}$ transect with a maximum elevation difference of $1,080 \mathrm{~m}$ in the southern Black Forest (Fig. 2).
Zircon FT central ages range from $136 \pm 16$ to $312 \pm 29 \mathrm{Ma}$ (Fig. 3 and Table 1). No regional trend is detectable in the spatial distribution of the age data. However, a vertical trend of increasing zircon FT central ages with elevation can be observed. Radial plots of zircon samples reveal broad single-grain age distributions from $\sim 500$ to $\sim 100 \mathrm{Ma}$ (Fig. 4). In all the cases except one (ZTG013), the wide spread of single-grain ages falls into the natural Poissonian variation as obtained by the applied $\chi^{2}$ statistics (Table 1); $P\left(\chi^{2}\right)$ values higher than $5 \%$ indicate that all grains of an individual sample belong to a single age population (Green 1981).

Apatite FT central ages range from $20 \pm 2$ to $83 \pm 12 \mathrm{Ma}$ (Fig. 3 and Table 2), the youngest ages are found in the proximity of the URG. Radial plots (Fig. 5) display a large spread of the single-grain ages between $\sim 100$ and $\sim 5 \mathrm{Ma}$. In most of the samples, several age populations are present as revealed by the $\chi^{2}$ statistics (Table 2). Track length distributions differ significantly in their shape from unimodal (e.g. ZTG013, ZTG015) to clearly bimodal (e.g. ZTG006, ZTG007, ZTG008, ZTG009, ZTG023). Confined mean track lengths range between 10.5 and $12.1 \mu \mathrm{m}$ with relatively large standard deviations of $\sim 2$ to $\sim 3 \mu \mathrm{m}$.
Fig. 3 Zircon (right side of bar) and apatite FT central ages (left side of bar) in Ma ordered according to the sections shown in Fig. $2 b$ showing some of the weak vertical trends discussed in the text. Their respective errors are presented on Figs. 4, 5, 7 and 8
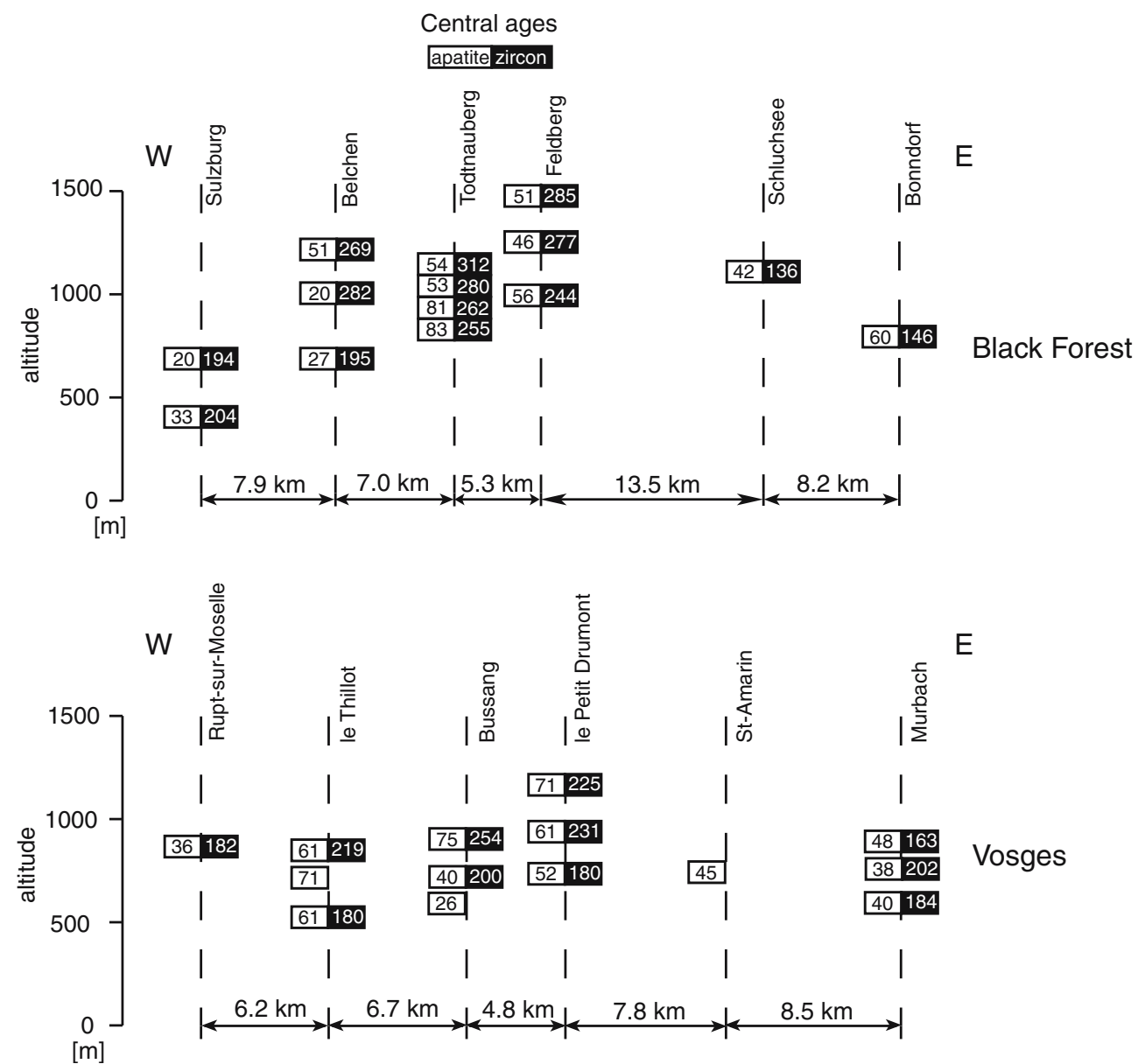


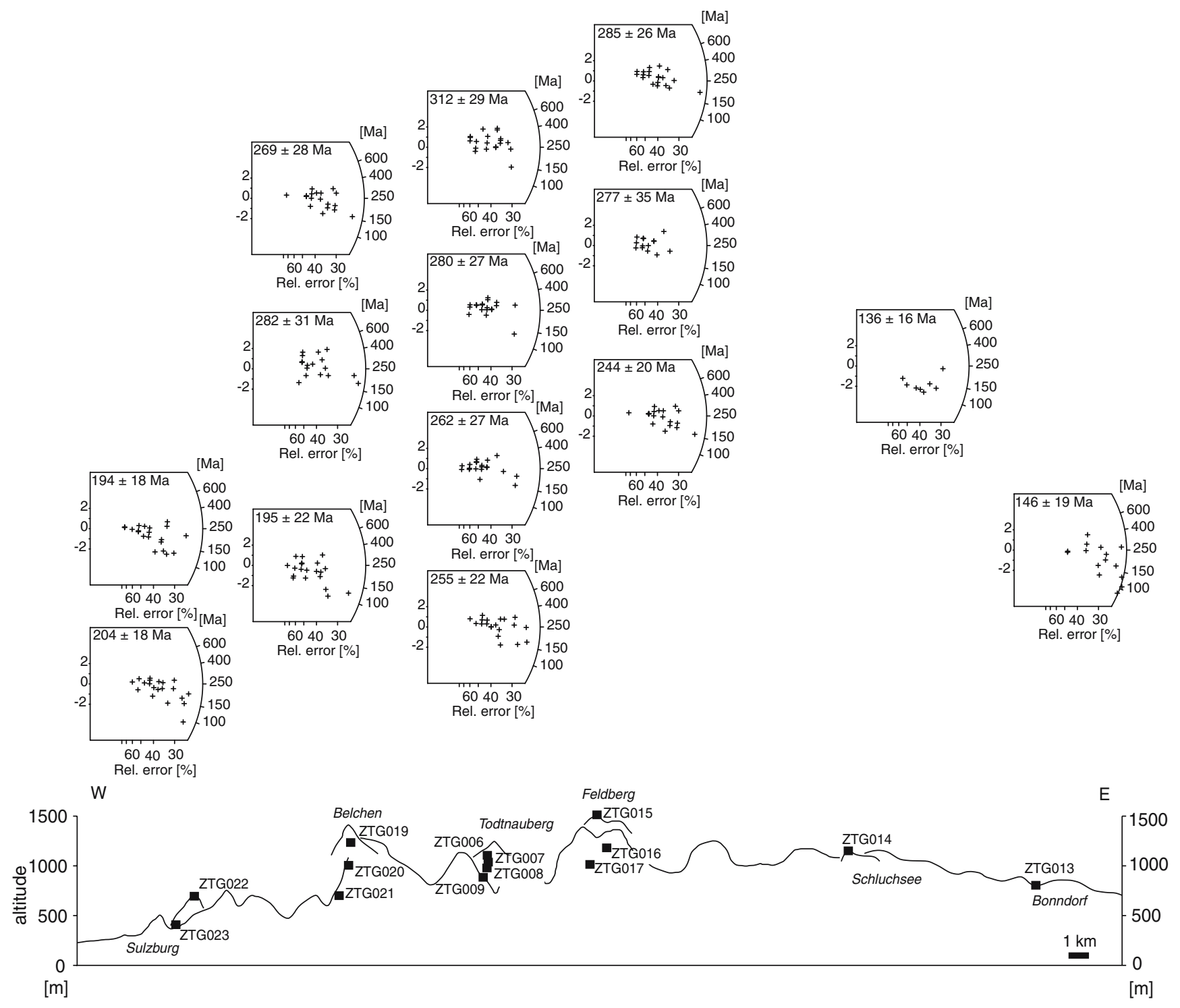

Fig. 4 Zircon FT radial plots of the Black Forest samples. An E-W topographic profile (vertical scale exaggerated by a factor of 5) with sample locations is shown at the bottom of the figure

Vosges

Along the second $\mathrm{E}-\mathrm{W}$ transect in the southern Vosges, another 14 basement samples were collected with an elevation difference of $640 \mathrm{~m}$ (Fig. 2).

Zircon FT central ages scatter between $163 \pm 16$ and $254 \pm 60 \mathrm{Ma}$ (Fig. 3 and Table 1) without a discernible regional trend. Single-grain ages (Fig. 7) range from $\sim 400$ to $\sim 100 \mathrm{Ma}$ with no statistical indication of an extra-Poissonian variation (except ZTG102, Table 1).

Apatite FT central ages range from $26 \pm 3$ to $75 \pm 5 \mathrm{Ma}$ (Fig. 3 and Table 2 ) and are evenly distributed over the entire area. The vertical FT age profiles show a weak tendency to increase with an increase in elevation. Radial plots (Fig. 8) reveal a spread of the single-grain ages from $\sim 100$ to $\sim 10 \mathrm{Ma}$. In most of the cases, $P\left(\chi^{2}\right)$ values are lower than $5 \%$ (Table 2 ), thus indicating an extra-Poissonian variation among singlegrain ages within individual samples. Bimodality in the track length distributions (Fig. 9) is less pronounced than in the Black Forest, but most of them are relatively broad. Confined mean track lengths range from 10.1 to $12.7 \mu \mathrm{m}$; their standard deviations are somewhat lower than in the Black Forest ranging from 1.7 to $2.3 \mu \mathrm{m}$.

\section{Thermal modelling of apatite FT data}

Thermal modelling of the FT parameters was carried out with the help of the computer programme AFTSolve (Ketcham et al. 2000) by using the Laslett et al. (1987) algorithm and an initial track length of $16.3 \mu \mathrm{m}$. By adopting the inverse modelling approach (for details see Ketcham et al. 2000) after careful selection of fitting 


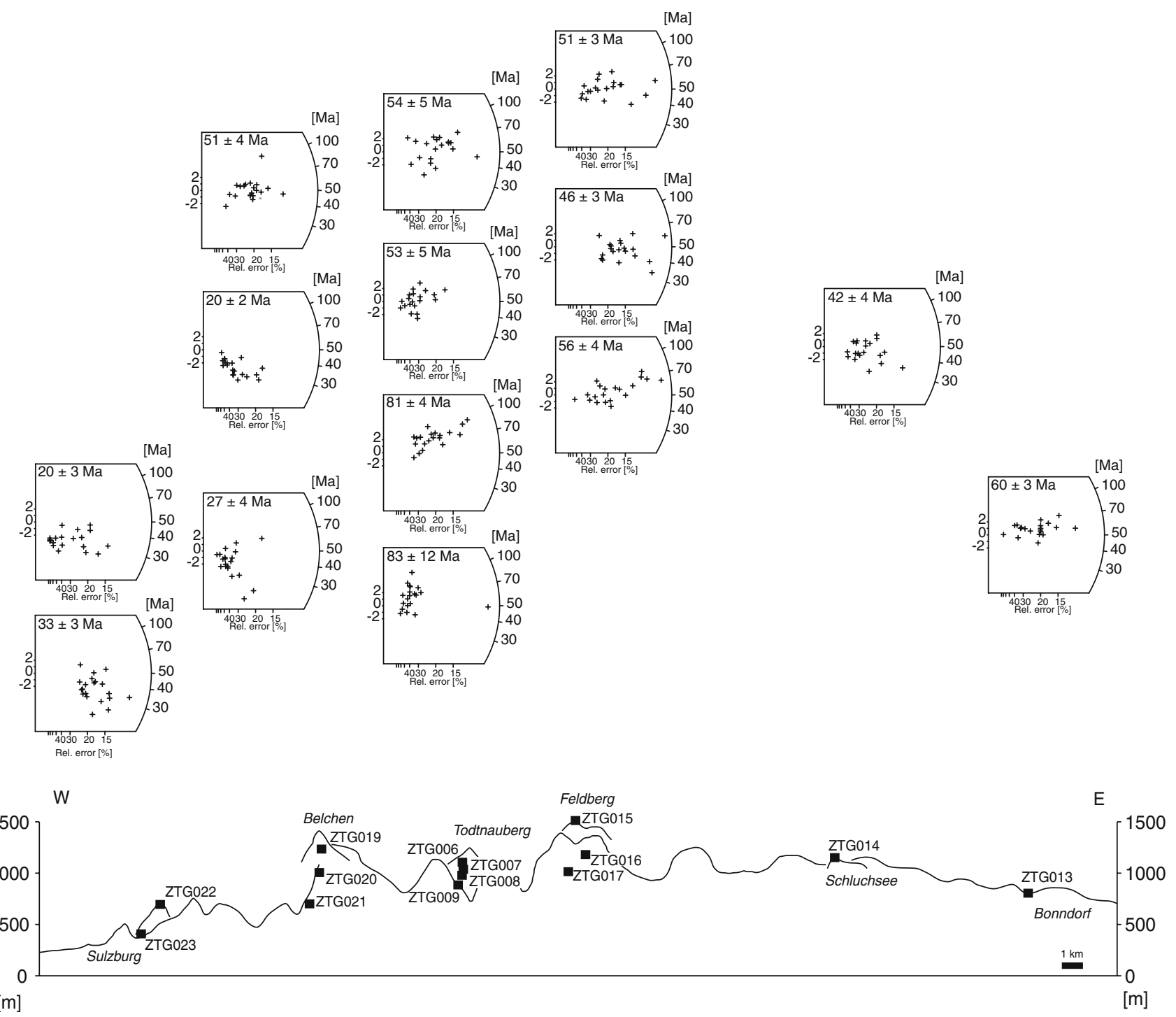

Fig. 5 Apatite FT radial plots of the Black Forest samples. An E-W topographic profile (vertical scale exaggerated by a factor of 5) with sample locations is shown at the bottom of the figure

conditions, i.e. time-temperature $(t-T)$ constraints that all cooling paths must pass through, thermal history information from apatite FT data could be derived, resulting in two differing portions of the $t-T$ space and a best-fit path (Figs. 10, 11). The outer envelope bounds all models that provide statistically "acceptable" fits (Kolmogorov-Smirnov probability $\geq 0.05$ ) and the inner envelope bounds all models that provide statistically "good" fits (Kolmogorov-Smirnov probability $\geq 0.5$ ). For an exact description of the underlying statistical tests, the reader is referred to Ketcham et al. (2000). Modelling of the FT parameters was an iterative process as model runs were gradually refined by forcing limitations on the $t-T$ paths as suggested by consecutive modelling results and geological observations. Modelling details are listed in Appendix.

\section{Black Forest}

Best-fit models of the Black Forest samples indicate that there was total annealing of apatite fission tracks in the Early Cretaceous (Fig. 10). One sample next to the eastern boundary of the URG (ZTG023) cooled below track retention temperature, i.e. $\sim 120^{\circ} \mathrm{C}$, not until the Palaeogene. Oldest tracks preserved in the best-fit models scatter between $43 \mathrm{Ma}$ (ZTG023) and $125 \mathrm{Ma}$ (ZTG009) and neither a regional trend nor a correlation with sample elevation is identifiable. Measured and predicted parameters of the best-fit paths are in very good agreement, with age goodness-of-fit values of up to 0.96 and Kolmogorov-Smirnov probabilities of up to 0.98 . The modelled $t-T$ paths of only one sample (ZTG013) failed to yield good fits to the measured data, 

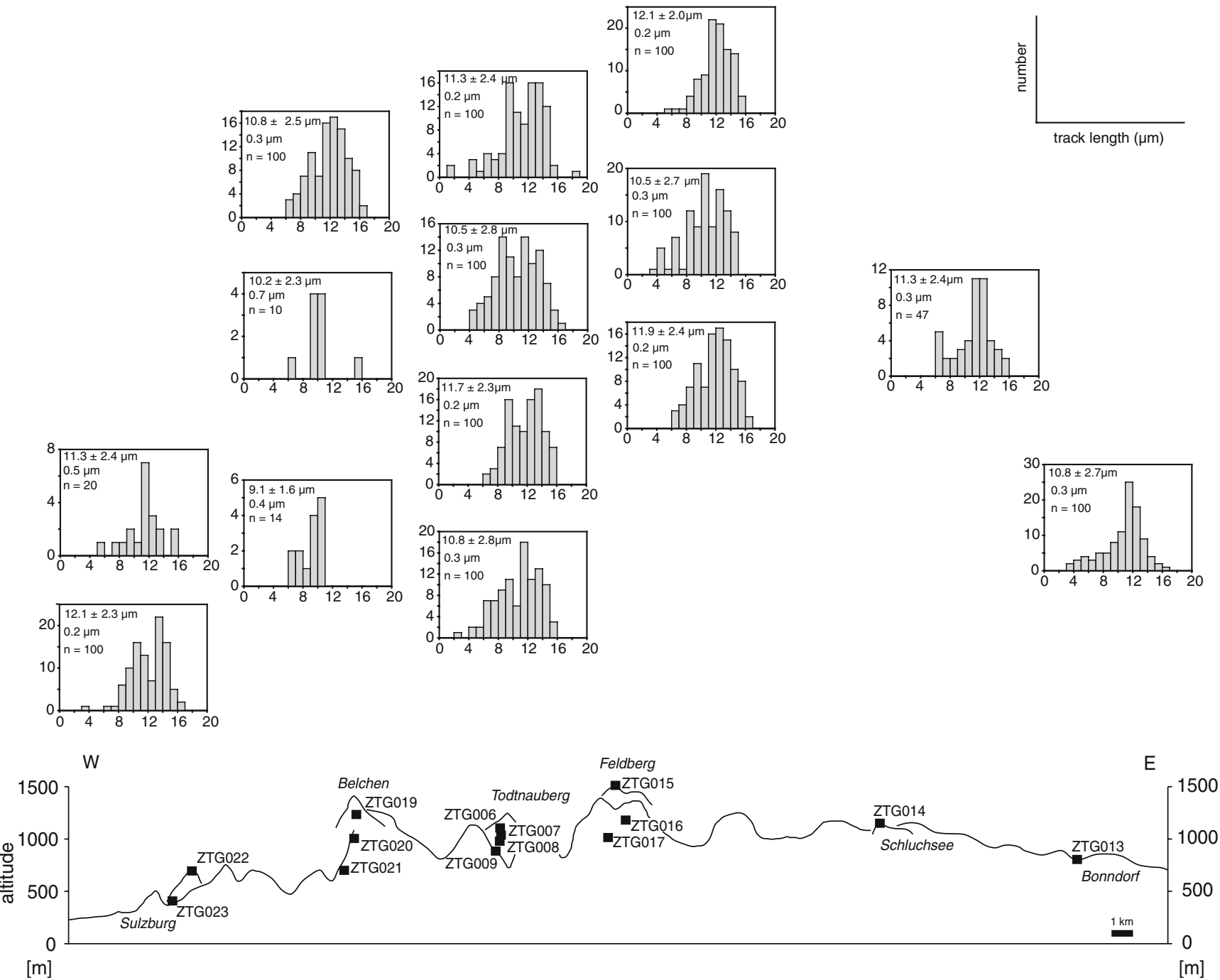

Fig. 6 Apatite FT length distributions of the Black Forest samples. An E-W topographic profile (vertical scale exaggerated by a factor of 5) with sample locations is shown at the bottom of the figure

but acceptable fits exhibit the same general shape as the best-fit paths of the other samples.

The modelled best-fit $t-T$ paths exhibit very similar thermal histories for all samples. Most samples cooled below the closure temperature of the apatite FT system in the Early Cretaceous. After moderate to slow cooling below $\sim 60^{\circ} \mathrm{C}$, a distinct heating event occurred in the late Eocene. This was followed firstly by slow, and then by accelerated cooling from the Miocene onwards.

\section{Vosges}

All of the samples experienced temperatures greater than $120^{\circ} \mathrm{C}$ in the Early Cretaceous and some of them also in the Palaeogene (Fig. 11). Best-fit models reveal oldest preserved tracks in apatite ranging between $128 \mathrm{Ma}$ (ZTG124) and $37 \mathrm{Ma}$ (ZTG122). Samples closer to the URG and from lower altitudes seemingly cooled later below the track retention temperature-with some exceptions (e.g. ZTG107) - than samples further to the $\mathrm{W}$ and from higher altitudes. Evaluation of the statistical goodness-of-fit of modelled FT length distributions and ages to the observed data results in values between 0.69 and 0.98 .

Most of the best-fit models display a two-phase cooling history, very similar to the ones obtained for the Black Forest samples. Cooling of the samples through the apatite PAZ in a time span ranging from the Early Cretaceous to the Palaeogene was followed by an Eocene heating event. The subsequent cooling phase is characterised by rapid late-stage cooling from the late Miocene onwards.

\section{Interpretation and discussion}

A question of open debate concerning the regional geology of the URG area is whether Cretaceous sediments were deposited and subsequently completely ero- 


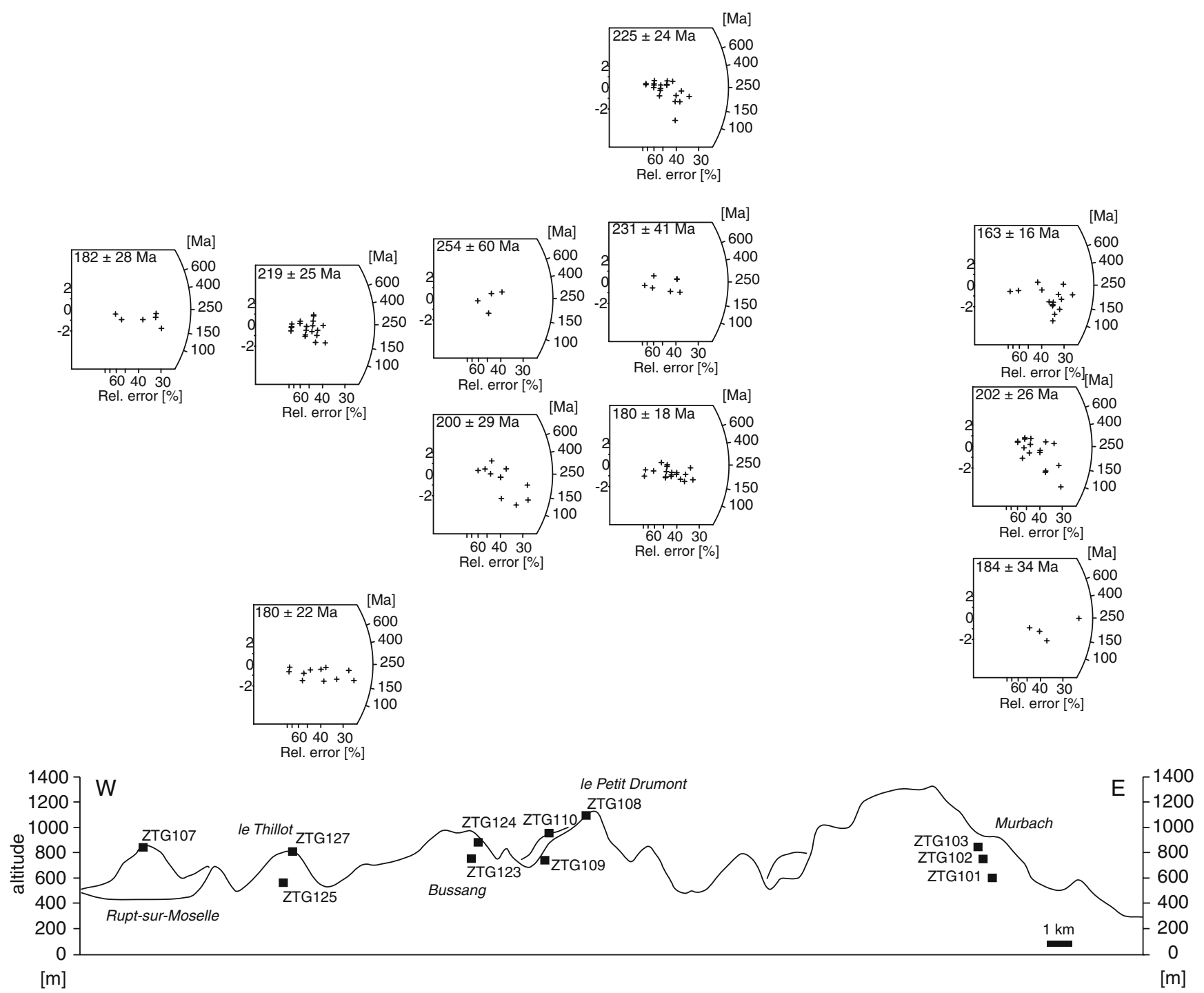

Fig. 7 Zircon FT radial plots of the Vosges samples. An E-W topographic profile (vertical scale exaggerated by a factor of 5) with sample locations is shown at the bottom of the figure

ded during the latest Cretaceous to the Paleocene (Ziegler 1990) or never existed (e.g. Geyer and Gwinner 1991). FT thermochronology can potentially contribute to the solution of this question, since it provides information on both paleotemperature and timing. The zircon FT data, particularly the existence of many grains with pre-Mesozoic ages, indicate that the sampled crustal segments never reached the critical temperature for complete track loss, i.e. $\sim 330^{\circ} \mathrm{C}$ (Tagami and Shimada 1996; Tagami et al. 1998), after post-Variscan peneplanation. Zircon FT central ages as well as singlegrain ages scatter significantly. $\chi^{2}$ statistics (Table 1 ) indicate that the observed large spread in single-grain ages generally does not represent a real difference to the respective apparent age because $P\left(\chi^{2}\right)$ values are (with exception of the sample ZTG102) consistently higher than 5\% (Green 1981). However, due to the low number of random samples (20 counted grains or fewer) and the high standard errors of single-grain age estimates the $\chi^{2}$ approach may lack power to detect any extra-Poissonian variation (Timar-Geng et al. 2004). Thus, the observed high spread may reflect different track retentivity of the individual grains within one sample, for instance due to variable amounts of accumulated $\alpha$ damage (Kasuya and Naeser 1988). Based on this assumption, the zircons with the youngest single-grain ages can be interpreted as having the lowest thermal stability because they are the last to close on a cooling path (Brandon et al. 1998). The youngest single-grain age represents the maximum age dating the passage of the sample through the cool limit of the zircon FT PAZ (Fügenschuh and Schmid 2003). Continuous hydrothermal activity in the Jurassic (e.g. Wernicke and Lippolt 1997; Wetzel et al. 2003) caused substantial annealing of fission tracks in zircon (TimarGeng et al. 2004) and a long residence time within the PAZ. This is also suggested by the broad distribution of zircon single-grain ages in the present dataset. Based on these observations it can be inferred that the sampled 


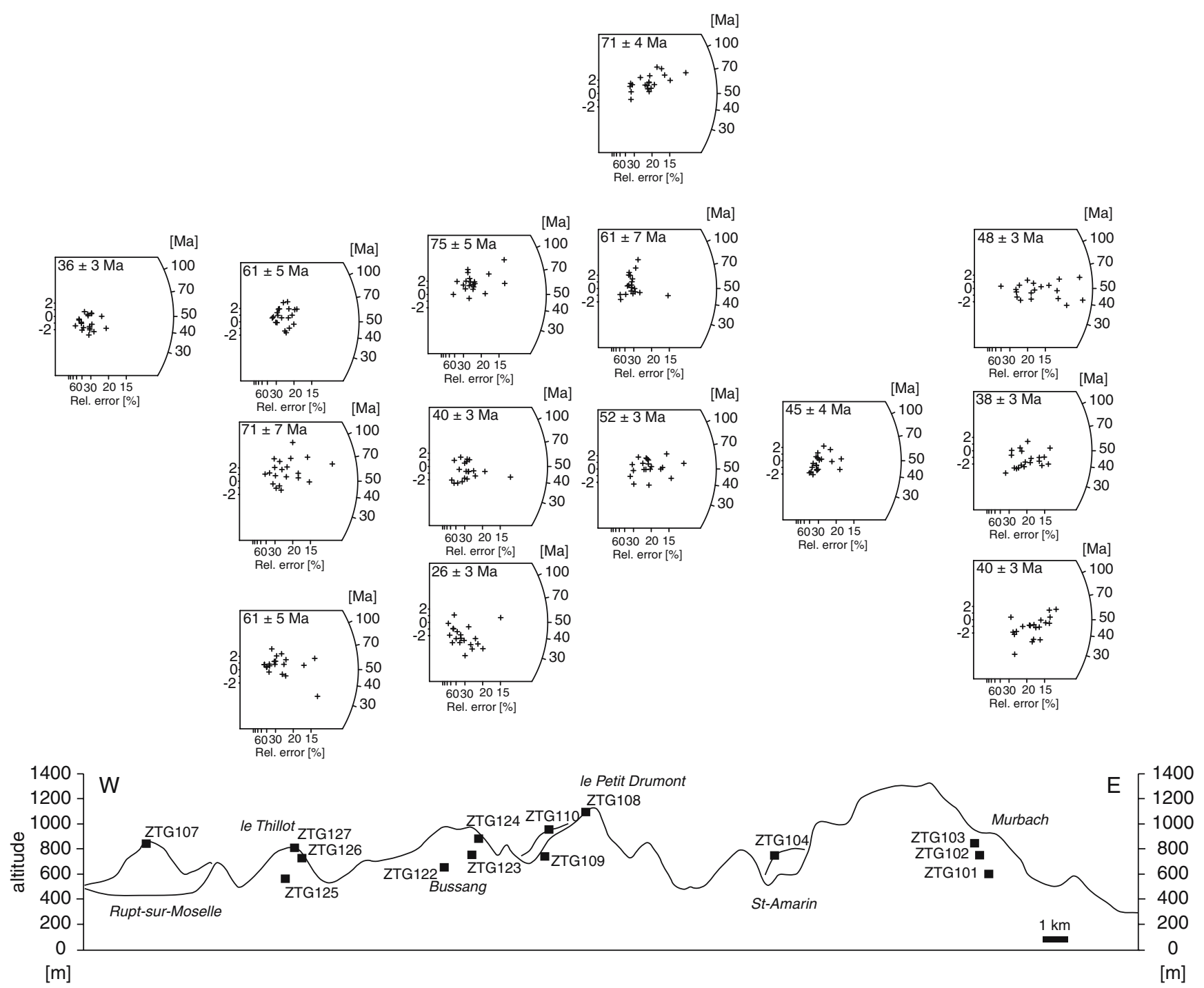

Fig. 8 Apatite FT radial plots of the Vosges samples. An E-W topographic profile (vertical scale exaggerated by a factor of 5) with sample locations is shown at the bottom of the figure

level of the crust cooled below $\sim 230^{\circ} \mathrm{C}$ (the cool limit of the zircon PAZ after Tagami et al. 1998) during the Early Cretaceous. Since the Permo-Triassic paleosurface is partly preserved in the southern Black Forest (e.g. Paul 1955; Wimmenauer and Schreiner 1990), it can be assumed that no significant erosion of the pre-Mesozoic basement has been occurred. Taking a generous estimate of $\sim 1,500 \mathrm{~m}$ Mesozoic sediment cover, based on interpolated isopach maps (e.g. Geyer and Gwinner 1991), it is obvious that the observed paleotemperatures in the Early Cretaceous cannot be due to burial alone (see also Timar-Geng et al. 2004), even not if a hypothetical kilometre-scale thick Upper Jurassic to Lower Cretaceous pile of sediments is assumed (Fig. 12).

The $t-T$ path between $\sim 230^{\circ} \mathrm{C}$, given by the youngest cluster of zircon FT single-grain ages, and $\sim 120^{\circ} \mathrm{C}$, marking the entrance of the samples into the apatite PAZ, is only poorly constrained. However, it appears that the Cretaceous must have been a period of acce- lerated cooling, since some of the modelled $t-T$ paths enter the apatite PAZ already at the end of the Early Cretaceous. This could have been caused primarily by the cessation of the hydrothermal activity in the area in combination with the uplift-induced erosion of the socalled "Rhenish Shield" (Cloos 1939).

From the Early Cretaceous onwards, the thermal history of the flanks of the southern URG is tightly constrained by the apatite FT modelling results. Best-fit models display a fairly common $t-T$ path for all samples with a two-phase cooling history. It starts with entering the apatite PAZ in Early Cretaceous to Palaeogene times depending on the position of the samples. Overall cooling is interrupted by a distinct heating event in the late Eocene that is invariably recorded by all samples. Subsequent cooling to surface temperatures is characterised by an accelerated rate from the Miocene onwards. This can reflect amplified erosion due to uplift of the Vosges-Black Forest area owing to lithospheric 

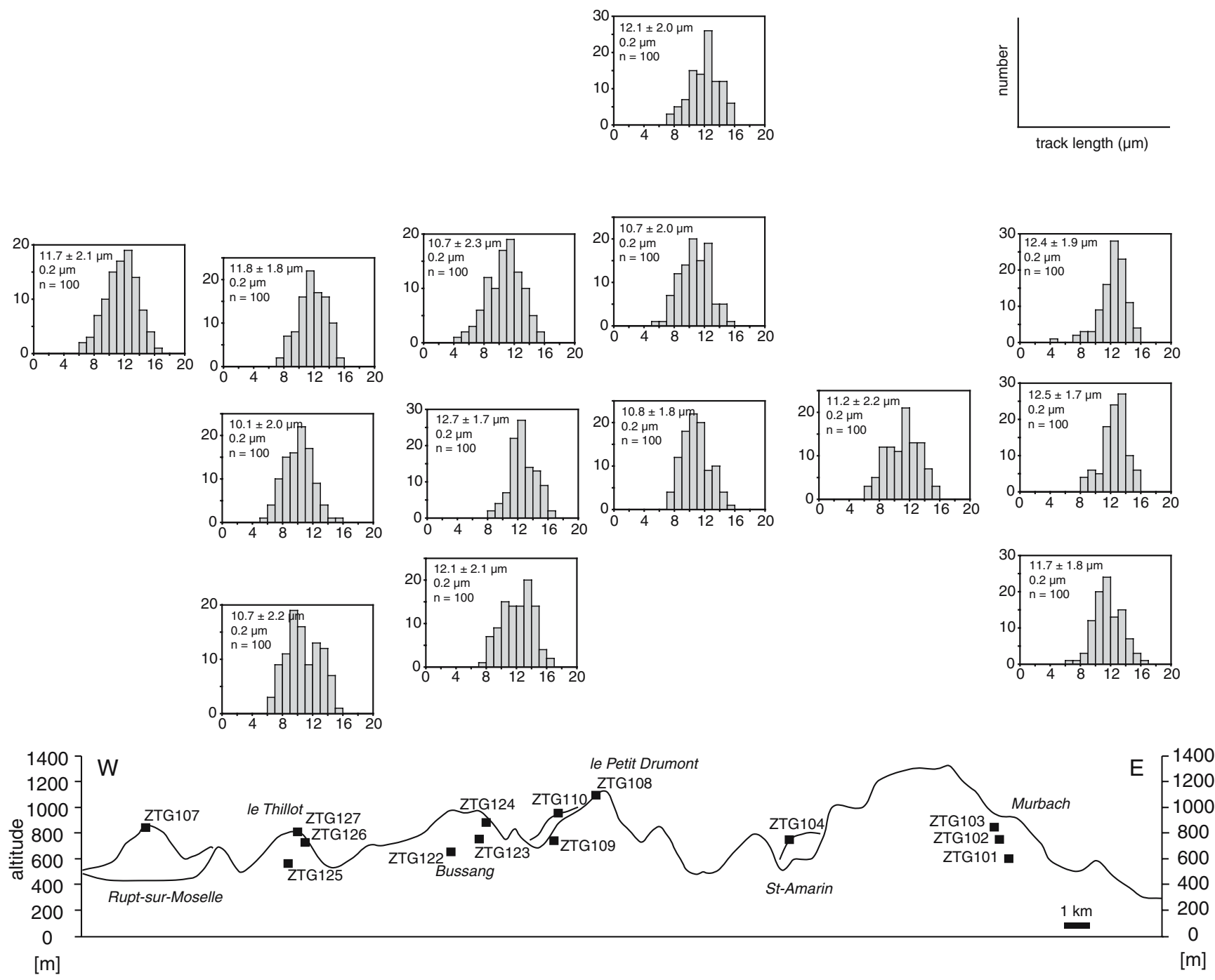

Fig. 9 Apatite FT length distributions of the Vosges samples. An E-W topographic profile (vertical scale exaggerated by a factor of 5) with sample locations is shown at the bottom of the figure

folding (Dèzes et al. 2004). However, this late cooling episode can also be an artefact of the Laslett et al. (1987) annealing model (e.g. Ketcham et al. 2000) and should be considered with caution. In contrast, the other parts of the $t-T$ paths, especially the timing of entry into the PAZ and the temperature maximum and timing of a transient heating episode, are well reconstructed by thermal modelling studies (Gleadow and Brown 2000). A complex cooling history is also evidenced by the frequent bimodal distributions of apatite FT lengths (e.g. the Todtnauberg profile in the Black Forest; Fig. 6). One generation of tracks is severely annealed (with track lengths of $8-10 \mu \mathrm{m}$ ) due to the Eocene thermal episode and a second generation formed after the temperature peak has longer tracks in the range of $12-14 \mu \mathrm{m}$.

To gain information on the denudation history of the flanks of the URG, two transects with an elevation difference of $640-1,080 \mathrm{~m}$ were sampled. Such a vertical reference frame can be used to estimate the rate of denudation (Gallagher et al. 1998). Samples collected over considerable relief often yield apatite FT ages that display a positive correlation with sample elevation (e.g. Wagner et al. 1977). For high denudation rates, such as in active orogenic belts, the gradients of the age-elevation profiles correspond closely to the denudation rates (Gleadow and Brown 2000). For low denudation rates, these linear profiles are replaced by concave-upwards curves and are interpreted as representing prolonged residence in the PAZ. In this case, the age-elevation profiles are not related to denudation rate. An important pre-requisite in order to obtain information on denudation from such profiles is that the samples were taken within a single tectonic unit. Another essential requirement is that the samples cover a significant range of vertical relief that may render possible to contain a complete frozen paleo-PAZ. Unfortunately, none of these preconditions are fulfilled in this study and the apatite FT age-elevation profiles (Fig. 13) show substantial disturbance. Even though, a tendency towards increasing ages with increasing elevation is recognizable 


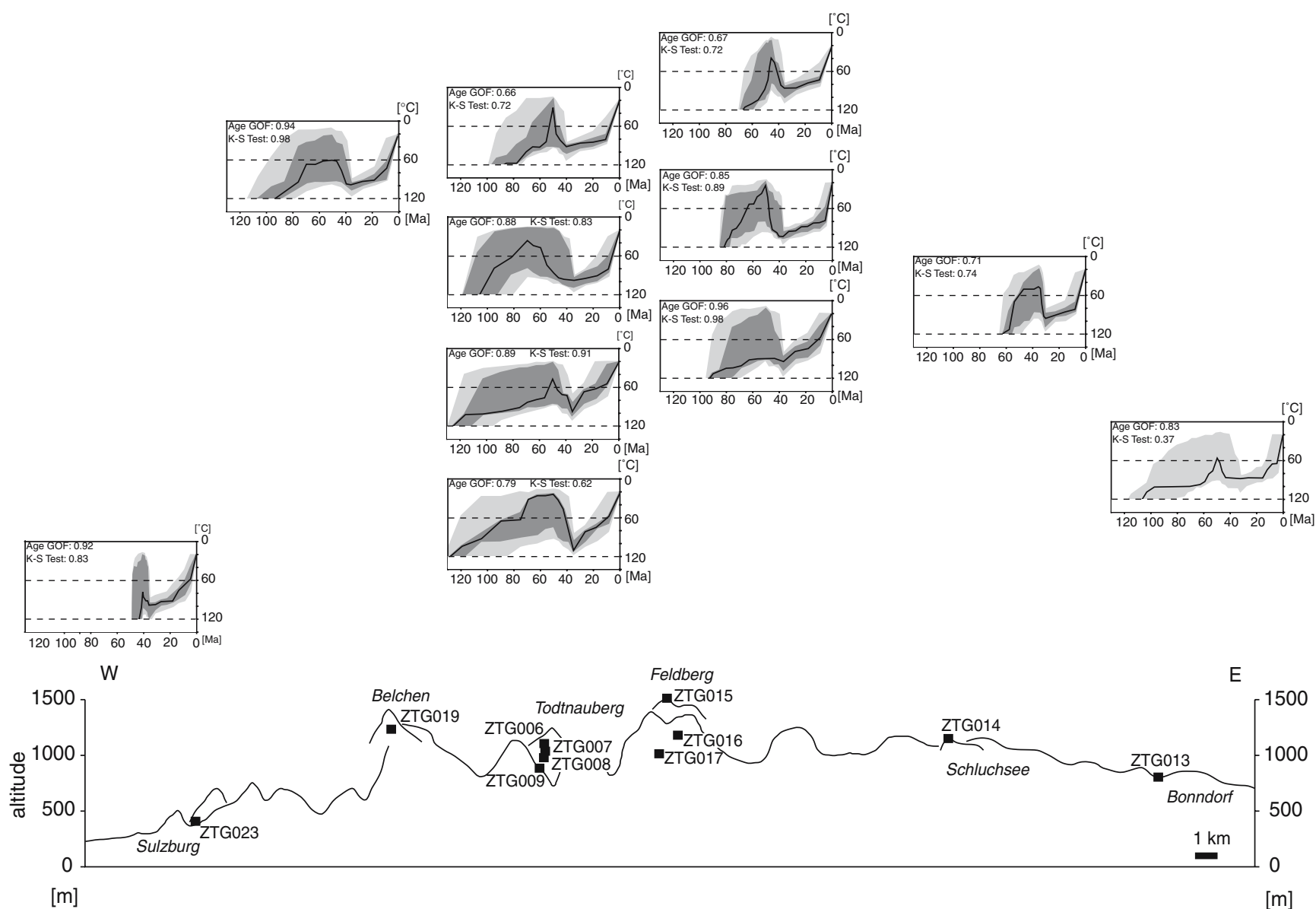

Fig. 10 Modelled best-fit $t-T$ paths and two envelopes covering the statistically "acceptable" fits (light grey) and "good" fits (dark grey) from the Black Forest. K-S test: Kolmogorov-Smirnov test evaluating the degree of fit between FT length distributions. Age

(Fig. 13). However, in the present case the distribution of FT age with elevation points to progressive annealing as a result of increasing temperature and it is not associated to any cooling rate. For a sound interpretation of the data in terms of a quantitative assessment of amount and rate of denudation, both FT age and length measurements have to be incorporated. Temperature and timing of the thermal maximum prior to the final cooling to surface temperatures are quite well determined from modelling studies (Gleadow and Brown 2000). These paleotemperature estimates can be used to derive constraints on the amount of denudation (e.g. Raab et al. 2002). Temperature can be equated to burial depth using the following equation:

$D=\left(T-\mathrm{T}_{\mathrm{s}}\right) / G$

where $D$ is the thickness of the denuded section $(\mathrm{km})$, $T$, the modelled paleotemperature $\left({ }^{\circ} \mathrm{C}\right], T_{\mathrm{s}}$, the surface temperature $\left({ }^{\circ} \mathrm{C}\right)$ and $G$, the geothermal gradient $\left({ }^{\circ} \mathrm{C} /\right.$ $\mathrm{km})$. Despite the considerable variation among the observed apatite FT ages, the modelled thermal histories suggest a common timing for the onset of the last cooling phase in the late Eocene. These $t-T$ points

GOF: FT age goodness-of-fit test. For methodological details, see Ketcham et al. (2000). An E-W topographic profile (vertical scale exaggerated by a factor of 5) with sample locations is shown at the bottom of the figure

can be used to estimate the amount of denudation since the late Eocene (Table 3). Modelling of the apatite FT parameters suggest a distinct heating episode in the late Eocene contemporaneous to the initial rifting phase of the URG (e.g. Schumacher 2002) and associated volcanic activity (Keller et al. 2002). This clearly points to a possible elevated paleogeothermal gradient during this time. The denudation estimates for gradients of 45 and $60^{\circ} \mathrm{C} / \mathrm{km}$ are given in Table 3. For the latter case, they range between 1.0 and $1.7 \mathrm{~km}$ correlating quite well with the present elevation of the samples (Fig. 14). Conversely, taking into account up to $1,500 \mathrm{~m}$, Mesozoic sedimentary rocks based on geological observations and the fact that only minor amounts of crystalline basement are being eroded, the observed annealing requires elevated paleotemperatures in the late Eocene.

Minor differences in the amount of denudation can be explained by Tertiary differential block movements. For example, in the eastern Vosges, N-NE trending Paleozoic discontinuities were reactivated as normal faults during the $\mathrm{E}-\mathrm{W}$ extension in the Oligocene (Edel and Fluck, 1989). 

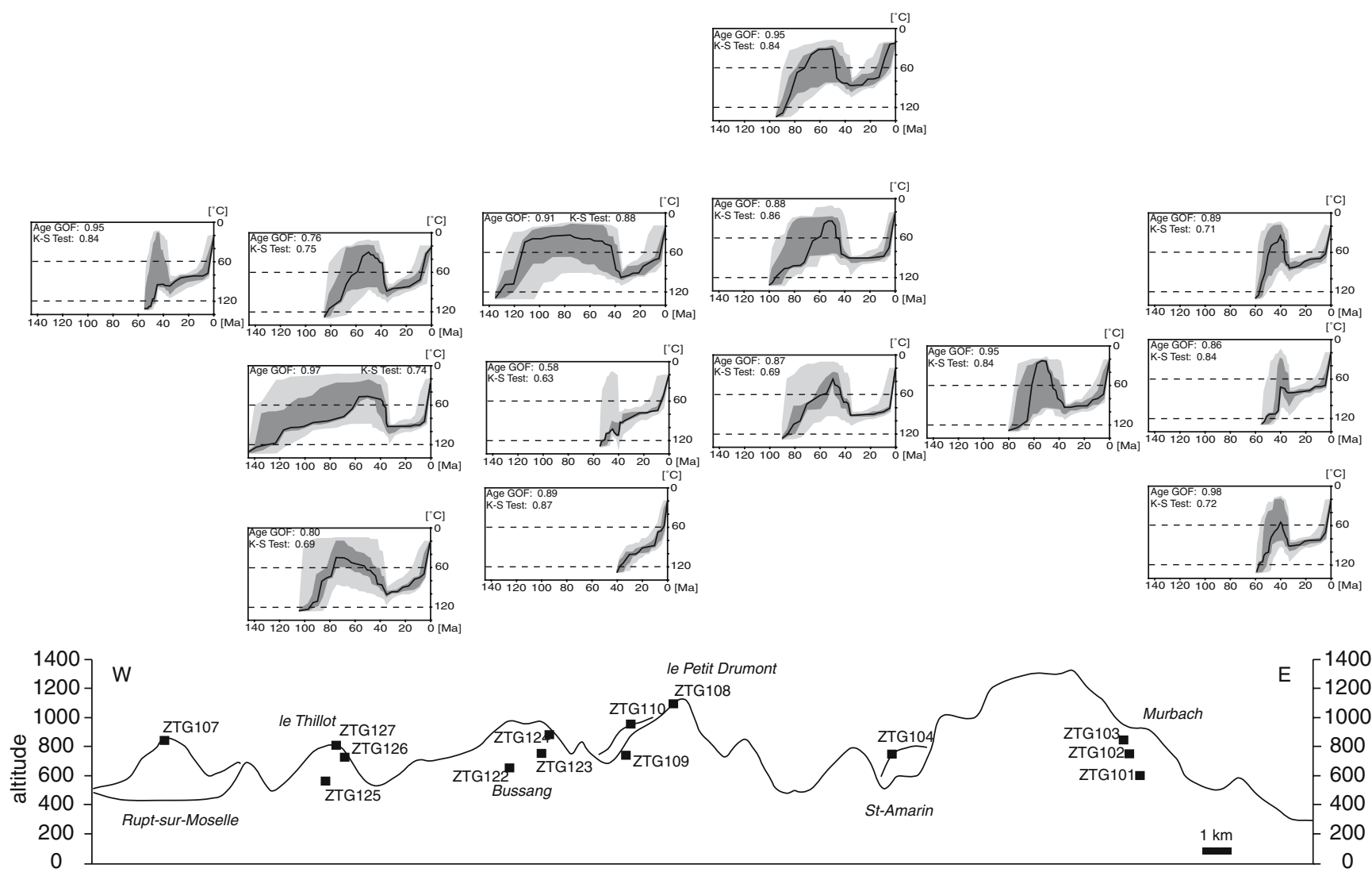

[m]

Fig. 11 Modelled best-fit $t-T$ paths and two envelops covering the statistically "acceptable" fits (light grey) and "good" fits (dark grey) from the Vosges. $\mathrm{K}-\mathrm{S}$ test: Kolmogorov-Smirnov test evaluating the degree of fit between FT length distributions. Age

It may be worthwhile noting explicitly that it is inappropriate to interpret the measured apatite FT ages in the URG as cooling ages, particularly, because one of

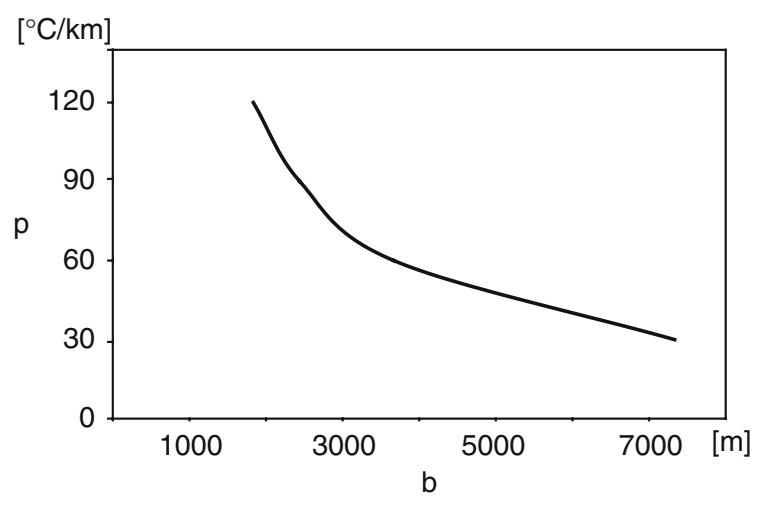

Fig. 12 Relationship between the paleogeothermal gradient $(p)$ and the hypothetical burial $(b)$ of the present earth's surface for the Early Cretaceous. Paleotemperature: $\sim 230^{\circ} \mathrm{C}$ (the cool limit of the zircon PAZ after Tagami et al. 1998); assumed surface temperature: $10^{\circ} \mathrm{C}$. The FT results cannot be explained by burial depth, since such high values up to $7 \mathrm{~km}$ are impossible to reconcile with the known geology of the URG area
GOF: FT age goodness-of-fit test. For methodological details, see Ketcham et al. (2000). An E-W topographic profile (vertical scale exaggerated by a factor of 5) with sample locations is shown at the bottom of the figure

several requirements, a steady-state paleogeothermal gradient, is definitively not met throughout the lowtemperature thermal history of the southern URG. The FT age-elevation profiles do not result from simple linear cooling in the upper crust.

\section{Conclusions}

The FT data demonstrate that the flanks of the southern URG have experienced a complex thermal history with repeatedly changing paleogeothermal gradients. Using an inverse modelling approach, the low-temperature thermal history of the area could be determined that is consistent with the measured FT dataset and independent geological observations.

Interpreting the youngest cluster of zircon FT singlegrain ages as the approximate date of cooling through the cool limit of the zircon FT PAZ, and interpolating the thickness of the Mesozoic sedimentary rocks from adjacent regions into the study area, it can be inferred that not even a hypothetical kilometre-thick cover of Upper Jurassic to Lower Cretaceous sediments could have caused the observed very high paleotemperatures. 

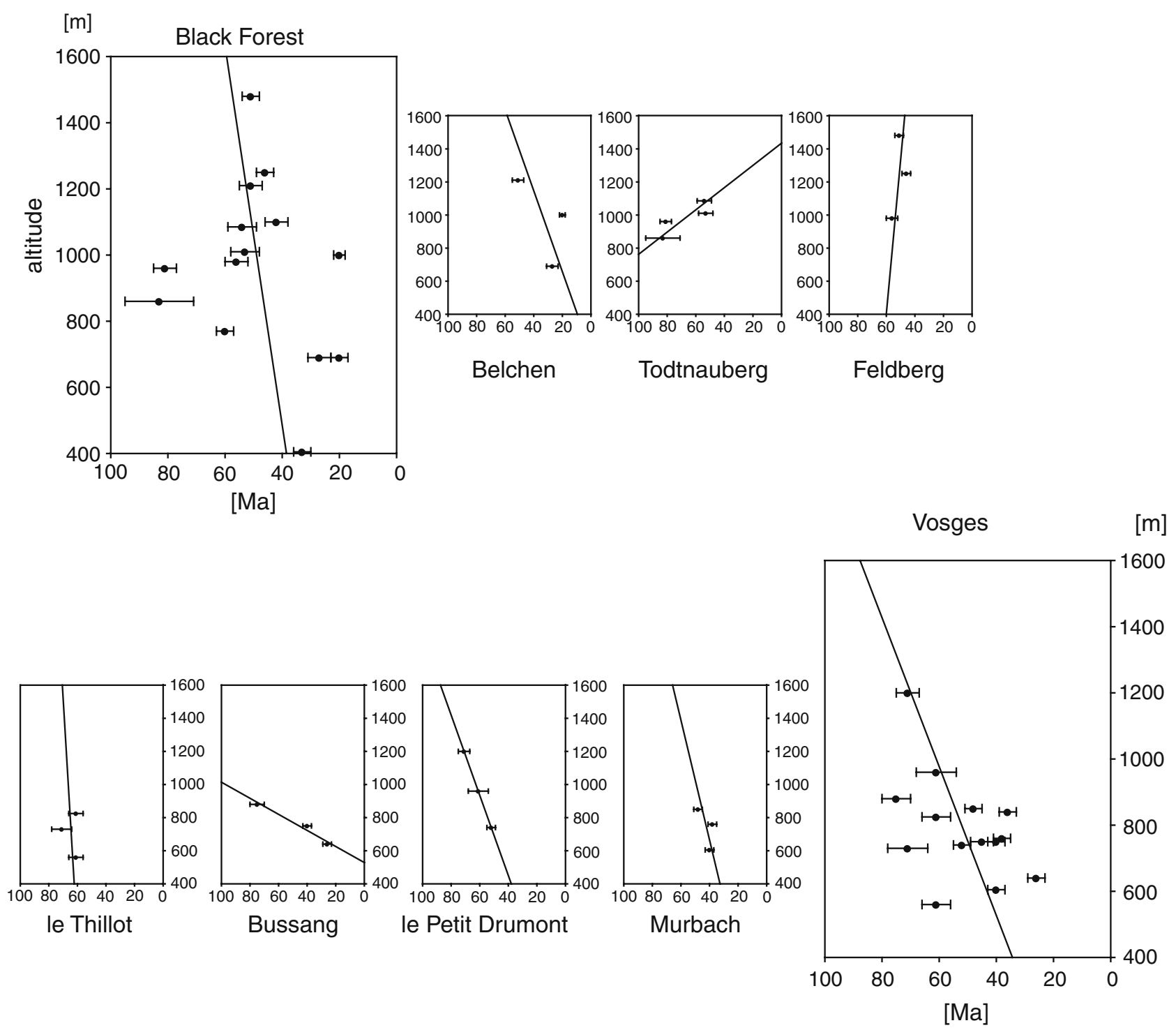

[m]

Vosges

\begin{tabular}{l}
1600 \\
1400 \\
1200 \\
1000 旁 \\
\hline$\frac{1}{ \pm}$
\end{tabular}

Fig. 13 Apatite FT age versus elevation profiles from the Black Forest and Vosges

The reason for the observed thermal anomaly is ascribed to one or (very probably) repeated Mesozoic hydrothermal episodes (see also Timar-Geng et al. 2004). Thus, the question regarding the thickness of the Cretaceous sediments in the southern URG area cannot be answered on the basis of FT analysis alone.

Modelling results provided a comprehensive thermal history of the study area from the Early Cretaceous to present. It is characterised by complex cooling with a transient heating episode in the late Eocene. This heating phase is contemporaneous to the initial rifting stage of the URG and associated with increased volcanic activity.

Based on best-fit $t-T$ paths and a tentative estimation of the prevailing paleogeothermal gradient in the late Eocene, the total amount of the denuded section from the flanks of the URG could be estimated. It amounts to
$1.0-1.7 \mathrm{~km}$ for a paleogeothermal gradient of $60^{\circ} \mathrm{C} / \mathrm{km}$ and $1.3-2.2 \mathrm{~km}$ for a paleogeothermal gradient of $45^{\circ} \mathrm{C} /$ $\mathrm{km}$, respectively.

Apatite FT central ages from the URG area not only record cooling due to tectonic uplift alone, but also due to decreasing hydrothermal activity. Therefore, no uplift rates based an age-elevation profiles can be derived. Convective heat transport seems to have played an important role throughout the post-Variscan thermotectonic evolution of the region. Therefore, only the thermal modelling approach can offer a meaningful interpretation of the growing amount of FT data.

Acknowledgements This work has been supported by the Swiss National Science Foundation (Project Nos. 21-57038.99 and 2064567.01). We thank M. Brix, U.A. Glasmacher and M. Rahn for their constructive comments and suggestions that substantially improved the manuscript. 
Table 3 Total amount of denudation for paleogeothermal gradients of 45 and $60^{\circ} \mathrm{C} / \mathrm{km}$ since the late Eocene

\begin{tabular}{llrll}
\hline Samples & $\begin{array}{l}\text { Timing of } \\
T_{\max }(\mathrm{Ma})\end{array}$ & $\begin{array}{r}T_{\max } \\
\left({ }^{\circ} \mathrm{C}\right)\end{array}$ & $\begin{array}{l}D(\mathrm{~km}) \text { for } \\
G=45^{\circ} \mathrm{C} / \mathrm{km}\end{array}$ & $\begin{array}{l}D(\mathrm{~km}) \mathrm{for} \\
G=60^{\circ} \mathrm{C} / \mathrm{km}\end{array}$ \\
\hline \multicolumn{2}{l}{ Black Forest } & & & \\
ZTG006 & 40 & 90 & 1.6 & 1.2 \\
ZTG007 & 36 & 97 & 1.7 & 1.3 \\
ZTG008 & 36 & 96 & 1.7 & 1.3 \\
ZTG009 & 36 & 110 & 2.0 & 1.5 \\
ZTG013 & 33 & 88 & 1.5 & 1.1 \\
ZTG014 & 30 & 93 & 1.6 & 1.2 \\
ZTG015 & 35 & 83 & 1.4 & 1.1 \\
ZTG016 & 38 & 103 & 1.8 & 1.4 \\
ZTG017 & 37 & 92 & 1.6 & 1.2 \\
ZTG019 & 36 & 99 & 1.8 & 1.3 \\
ZTG023 & 35 & 96 & 1.7 & 1.3 \\
Vosges & & & & \\
ZTG101 & 33 & 90 & 1.6 & 1.2 \\
ZTG102 & 33 & 80 & 1.3 & 1.0 \\
ZTG103 & 33 & 80 & 1.3 & 1.0 \\
ZTG104 & 36 & 91 & 1.6 & 1.2 \\
ZTG107 & 35 & 96 & 1.7 & 1.3 \\
ZTG108 & 35 & 84 & 1.4 & 1.1 \\
ZTG109 & 36 & 92 & 1.6 & 1.2 \\
ZTG110 & 36 & 88 & 1.5 & 1.1 \\
ZTG122 & 38 & 120 & 2.2 & 1.7 \\
ZTG123 & 40 & 111 & 2.0 & 1.5 \\
ZTG124 & 36 & 98 & 1.7 & 1.3 \\
ZTG125 & 35 & 103 & 1.8 & 1.4 \\
ZTG126 & 34 & 91 & 1.6 & 1.1 \\
ZTG127 & 35 & 88 & 1.5 & \\
\hline & & & & \\
\hline
\end{tabular}

\section{Appendix}

Modelling details

This appendix (Table. 4, 5) contains information about parameters used for inverse modelling. The time for the first constraint was chosen based on the consideration that this time should be somewhat earlier than the FT age of the oldest and thus most resistant apatite grains to allow for age reduction by partial annealing (Ketcham et al. 2000). Thus, the temperature for the first constraint was set at $\sim 130^{\circ} \mathrm{C}$ providing that there are no fission tracks present as an initial condition. Modelled $t-T$ paths were initially defined to be non-monotonic, aiming at finding solutions by the program, particularly any possible heating events and their timing. The initial model runs also constrain the time of cooling below the track retention temperature, which can be used as initial constraints for subsequent model runs. In a next step, the new initial constraint and additional intermediate constraints were used to better evaluate individual heating and cooling events. Model runs were so gradually refined by forcing restrictions on the $t-T$ paths as suggested by consecutive modelling results and geological observations.
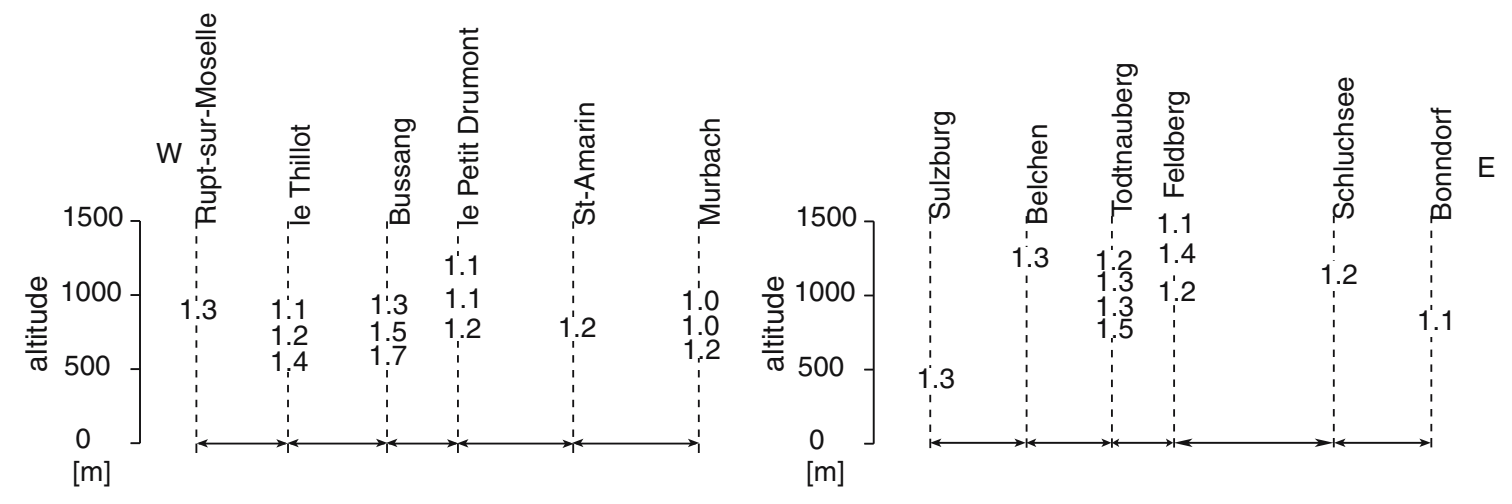

Fig. 14 Amount of denudation since the late Eocene for an assumed paleogeothermal gradient of $60^{\circ} \mathrm{C} / \mathrm{km}$. Values ordered according to the schematic profiles from Fig. $2 b$

Table 4 Modelling details of the Black Forest samples

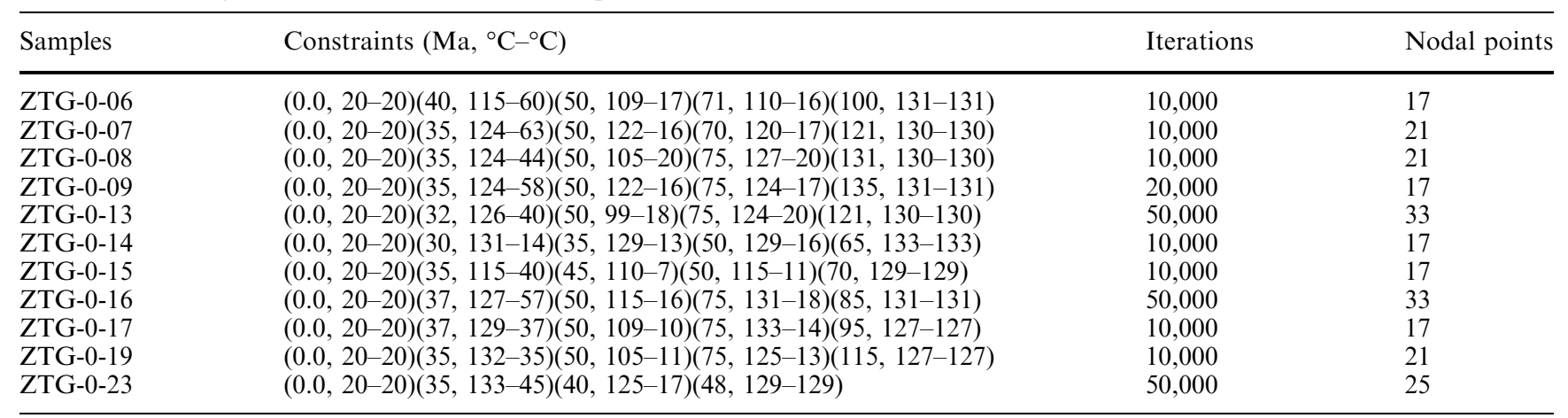


Table 5 Modelling details of the Vosges samples

\begin{tabular}{|c|c|c|c|}
\hline Samples & Constraints $\left(\mathrm{Ma},{ }^{\circ} \mathrm{C}-{ }^{\circ} \mathrm{C}\right)$ & Iterations & Nodal points \\
\hline ZTG-1-01 & $(0.0,20-20)(33,129-47)(40,103-17)(50,130-20)(60,130-130)$ & 50,000 & 33 \\
\hline ZTG-1-02 & $(0.0,20-20)(33,129-59)(40,130-16)(55,128-128)$ & 50,000 & 25 \\
\hline ZTG-1-03 & $(0.0,20-20)(33,105-49)(40,87-16)(60,129-129)$ & 50,000 & 25 \\
\hline ZTG-1-04 & $(0.0,20-20)(35,128-41)(50,128-16)(80,129-129)$ & 10,000 & 25 \\
\hline ZTG-1-07 & $(0.0,20-20)(35,131-28)(45,106-14)(55,132-132)$ & 40,000 & 25 \\
\hline ZTG-1-08 & $(0.0,20-20)(35,131-16)(50,102-17)(95,131-131)$ & 10,000 & 25 \\
\hline ZTG-1-09 & $(0.0,20-20)(35,112-64)(50,93-11)(91,127-127)$ & 100,000 & 25 \\
\hline ZTG-1-10 & $(0.0,20-20)(35,124-34)(50,105-8)(75,129-16)(101,131-131)$ & 20,000 & 33 \\
\hline ZTG-1-22 & $(0.0,20-20)(40,127-127)$ & 10,000 & 33 \\
\hline ZTG-1-23 & $(0.0,20-20)(35,127-14)(40,129-16)(45,127-16)(55,127-127)$ & 30,000 & 33 \\
\hline ZTG-1-24 & $(0.0,20-20)(35,130-45)(50,127-18)(75,127-16)(135,129-129)$ & 10,000 & 33 \\
\hline ZTG-1-25 & $(0.0,20-20)(35,125-46)(50,127-14)(75,126-15)(105,125-125)$ & 10,000 & 33 \\
\hline ZTG-1-26 & $(0.0,20-20)(33,118-65)(40,110-17)(50,102-12)(100,107-12)(145,132-132)$ & 100,000 & 49 \\
\hline ZTG-1-27 & $(0.0,20-20)(35,129-49)(50,129-13)(85,129-129)$ & 10,000 & 25 \\
\hline
\end{tabular}

\section{References}

Brandon MT, Roden-Tice MK, Garver JI (1998) Late Cenozoic exhumation of the Cascadia accretionary wedge in the Olympic Mountains, northwest Washington State. Geol Soc Am Bull 110:985-1009

Carlson WD (1990) Mechanisms and kinetics of apatite fissiontrack annealing. Am Mineral 75:1120-1139

Cloos H (1939) Hebung-Spaltung-Vulkanismus. Geologische Rundschau 30:401-527

Crowley KD, Cameron M, Schaefer RL (1991) Experimental studies of annealing etched fission tracks in fluorapatite. Geochimica et Cosmochimica Acta 55:1449-1465

Dèzes P, Schmid SM, Ziegler PA (2004) Evolution of the Alpine and Pyrenean orogens with their foreland lithosphere. Tectonophysics 389:1-33

Dumitru TA (1993) A new computer-automated microscope stage system for fission-track analysis. Nucl Tracks Radiat Meas 21:575-580

Dunkl I (2002) TRACKKEY: a Windows program for calculation and graphical presentation of fission track data. Comput Geosci 28:3-12

Edel JB, Fluck P (1989) The upper Rhenish Shield basement (Vosges, Upper Rhinegraben and Schwarzwald): Main structural features deduced from magnetic, gravimetric and geological data. Tectonophysics 169:303-316

Foster DA, Gleadow AJW (1996) Structural framework and denudation history of the flanks of the Kenya and Anza Rifts, East Africa. Tectonics 15:258-271

Foster DA, Gleadow AJW, Reynolds SJ, Fitzgerald PF (1993) The denudation of metamorphic core complexes and the reconstruction of the Transition Zone, west central Arizona: constraints from apatite fission track thermochronology. J Geophys Res 98:2167-2185

Foster DA, Raza A (2002) Low-temperature thermochronological record of exhumation of the Bitterroot metamorphic core complex, northern Cordilleran Orogen. Tectonophysics 349:2336

Fuchs K, Bonjer K-P, Gajewski D, Lueschen E, Prodehl C, Sandmeier K-J, Wenzel F, Wilhelm H (1987) Crustal Evolution of the Rhinegraben area. 1. Exploring rhe lower crust in the Rhinegraben rift by unified geophysical experiments. Tectonophysics 141:261-275

Fügenschuh B, Schmid SM (2003) Late stages of deformation and exhumation of an orogen constrained by fission-track data: a case study in the Western Alps. Geol Soc Am Bull 115:14251440

Galbraith RF (1988) Graphical display of estimates having differing standard errors. Technometrics 30:271-281
Galbraith RF (1990) The radial plot: graphical assessment of spread in ages. Nucl Tracks Radiat Meas 17:207-214

Galbraith RF, Laslett GM (1993) Statistical models for mixed fission track ages. Nucl Tracks Radiat Meas 21:459-470

Gallagher K, Brown RW, Johnson C (1998) Fission track analysis and its applications to geological problems. Ann Rev Earth Planet Sci 26:519-572

Geyer OF, Gwinner MP (1991) Geologie von Baden-Württemberg. 4., neubearb Aufl der "Einführung in die Geologie von BadenWürttemberg". Schweizerbart, Stuttgart

Giamboni M, Ustaszewski K, Schmid SM, Schumacher ME, Wetzel A (2004) Plio-Pleistocene transpressional reactivation of Paleozoic and Paleogene structures in the Rhine-Bresse transform zone (northern Switzerland and eastern France). Int J Earth Sci 93:207-223

Gleadow AJW (1981) Fission track dating: what are the real alternatives. Nucl Tracks Radiat Meas 5:3-14

Gleadow AJW, Brown RW (2000) Fission-track thermochronology and the long-term denudational response to tectonics. In: Summerfield MA (ed) Geomorphology and global tectonics. Wiley, New York, pp 57-75

Green PF (1981) A new look at statistics in fission track dating. Nucl Tracks Radiat Meas 5:77-86

Hurford AJ (1990) International Union of Geological Sciences Subcommission on Geochronology recommendation for the standardization of fission track dating calibration and data reporting. Nucl Tracks Radiat Meas 17:233-236

Hurford A, Carter A (1994) Regional thermo-tectonic histories of the Rhine Graben and adjacent Hercynian basement: a key to assessing the alpine influence in northwest Europe. In: 8th International Conference on Geochronology, Cosmochronology and Isotope Geology, abstracts, p 148

Hurford AJ, Green PF (1982) A users' guide to fission track dating calibration. Earth Planet Sci Lett 59:343-354

Hurford AJ, Green PF (1983) The zeta age calibration of fissiontrack dating. Chem Geol 41:285-317

Illies JH (1977) Ancient and recent rifting in the Rhinegraben. Geologie en Mijnbouw 56:329-350

Illies JH, Fuchs K (eds) (1974) Approaches to taphrogenesis. Schweizerbart, Stuttgart, p 460

Illies JH, Müller S (eds) (1970) Graben problems. Schweizerbart, Stuttgart, p 316

Kasuya M, Naeser CW (1988) The effect of $\alpha$-damage on fissiontrack annealing in zircon. Nucl Tracks Radiat Meas 14:477-480

Keller J, Kraml M, Henjes-Kunst F (2002) ${ }^{40} \mathrm{Ar} /{ }^{39} \mathrm{Ar}$ single crystal dating of early volcanism in the Upper Rhine Graben and tectonic implications. Schweiz Mineral Petrogr Mitt 82:121-130

Ketcham RA, Donelick RA, Carlson WD (1999) Variability of apatite fission-track annealing kinetics III: Extrapolation to geological time scales. Am Mineral 84:1235-1255 
Ketcham RA, Donelick RA, Donelick MB (2000) AFTSolve: a program for multi-kinetic modelling of apatite fission track data. Geol Mater Res 2:1-18

Laslett GM, Galbraith RF (1996) Statistical modelling of thermal annealing of fission tracks in apatite. Geochim Cosmochim Acta 60:5117-5131

Laslett GM, Green PF, Duddy IR, Gleadow AJW (1987) Thermal annealing of fission tracks in apatite 2. A quantitative analysis. Chem Geol (Isot Geosci Sect) 65:1-13

Michalski I (1987) Apatit-Spaltspuren-Datierungen des Grundgebirges von Schwarzwald und Vogesen: Die postvariszische Entwicklung. Doctoral dissertation, Heidelberg, p 125

Naeser CW (1976) Fission-track dating. US Geol Surv Open-File Rep 76-190, pp 65

Naeser CW (1979) Thermal history of sedimentary basins: fission track dating of subsurface rocks. In: Scholle PA, Schluger PR (eds) Aspects of diagenesis. Soc Econ Paleontol Mineral Spec Publ, SEPM, Tulsa OK United States, pp 109-112

Paul W (1955) Zur Morphogenese des Schwarzwaldes (I). Jh geol Landesamt Baden-Württ 1:395-427

Price PB, Walker RM (1962a) A new detector for heavy particle studies. Phys Lett 3:113-115

Price PB, Walker RM (1962b) Observations of charged-particle tracks in solids. J Appl Phys 33:3407-3406

Prodehl C, Mueller S, Haak V (1995) The European Cenozoic rift system. In: Olsen KH (ed) Continental rifts: evolution, structure, tectonics. Developments in geotectonics 25. Elsevier, New York, pp 133-212

Raab MJ, Brown RW, Gallagher K, Carter A, Weber K (2002) Late Cretaceous reactivation of major crustal shear zones in northern Namibia: constraints from apatite fission track analysis. Tectonophysics 349:75-92

Rothé JP, Sauer K (eds) (1967) The Rhinegraben progress report 1967. Abh Geol Landesamt Baden-Württemberg 6, pp 146

Schumacher ME (2002) Upper Rhine Graben: role of preexisting structures during rift evolution. Tectonics 21:6-1-17

Tagami T, Shimada C (1996) Natural long-term annealing of the zircon fission track system around a granitic pluton. J Geophys Res 101/B4:8245-8255

Tagami T, Galbraith RF, Yamada R, Laslett GM (1998) Revised annealing kinetics of fission tracks in zircon and geological implications. In: Van den Haute P, De Corte F (eds)Advances in fission track geochronology. Kluwer, Dordrecht, pp 99-112
Timar-Geng Z, Fügenschuh B, Schaltegger U, Wetzel A (2004) The impact of the Jurassic hydrothermal activity on zircon fission track data from the southern Upper Rhine Graben area. Schweiz Mineral Petrogr Mitt 84:257-269

von Gehlen K (1987) Formation of Pb-Zn-F-Ba mineralizations in SW Germany: a status report. Fortschr Miner 65:87-113

Wagner GA (1979) Correction and interpretation of fission track ages. In: Jäger E, Hunziker JC (eds) Lectures in isotope geology. Springer, Berlin Heidelberg New York, pp 170-177

Wagner GA (1990) Apatite fission-track dating of the crystalline basement of Middle Europe: concepts and results. Nucl Tracks Radiat Meas 17:277-282

Wagner GA, Reimer GM, Jäger E (1977) Cooling ages derived by apatite fission track, mica $\mathrm{Rb}-\mathrm{Sr}$, and $\mathrm{K}-\mathrm{Ar}$ dating: the uplift and cooling history of the central Alps. Mem Inst Geol Mineral Univ Padova 30:1-27

Wagner GA, Michalski I, Zaun P (1989) Apatite fission-track dating of the Central European basement: post-Variscian thermotectonic evolution. In: The German Continental Deep Drilling Program (KTB). Springer, Berlin Heidelberg New York, pp 481-500

Werner W, Franzke HJ (2001) Postvariszische bis neogene Bruchtektonik und Mineralisation im südlichen Zentralschwarzwald. Z Dt Geol Ges 152:405-437

Wernicke RS, Lippolt HJ (1997) (U + Th)-He evidence of Jurassic continuous hydrothermal activity in the Schwarzwald basement, Germany. Chem Geol 138:273-285

Wetzel A, Allenbach R, Allia V (2003) Reactivated basement structures affecting the sedimentary facies in a tectonically "quiescent" epicontinental basin: an example from NW Switzerland. Sediment Geol 157:153-172

Wimmenauer W, Schreiner A (1990) Erläuterungen zu Blatt 8114 Feldberg. Geol Karte Baden-Württ 1:25 000, Stuttgart, p 134

Wyss A (2001) Apatit Spaltspur Untersuchungen in der Vorwaldscholle (SW-Deutschland). Unpubl diploma thesis, Univ Basel, p 69

Ziegler PA (1990) Geological atlas of Western and Central Europe. Shell Internationale Petroleum Maatschappij, Geological Society Publishing House, London, p 239

Ziegler PA, Cloething S, van Wees J-D (1995) Dynamics of intraplate compressional deformation: the Alpine foreland and other examples. Tectonophysics 252:7-59 